\title{
14. VARIATIONS IN PLANKTONIC FORAMINIFER FAUNAS AND CARBONATE PRESERVATION AT SITE 927: EVIDENCE FOR CHANGING SURFACE WATER CONDITIONS IN THE WESTERN TROPICAL ATLANTIC OCEAN DURING THE MIDDLE PLEISTOCENE ${ }^{1}$
}

\author{
James L. Cullen ${ }^{2}$ and William B. Curry ${ }^{3}$
}

\begin{abstract}
Site 927 was cored during Leg 154 of the Ocean Drilling Program at a depth of $3315 \mathrm{~m}$ on the northeast flank of the Ceara Rise beneath the pool of warm, nutrient-depleted waters of the western tropical Atlantic Ocean. The site was triple advanced hydraulic piston cored and a composite section was constructed by the shipboard scientific party. We sampled the composite section between 23 and 43 meters composite depth $(\mathrm{mcd})$ at $10-\mathrm{cm}$ spacing (200 samples) and produced records of changing surface water conditions and carbonate preservation between 500 and $1000 \mathrm{ka}$ (time scale of Bickert et al., Chapter 15, this volume). Our record of changing surface water conditions is based on downcore variations in the relative abundances of planktonic foraminifers examined within the context of changes in foraminifer preservation, calcium carbonate content, coarse fraction content $(>63 \mu \mathrm{m})$, and the $\delta^{18} \mathrm{O}$ content of size-controlled specimens of Globigerinoides sacculifer.

Site 927 sediments exhibit systematic cyclic downcore changes in carbonate content and other indicators of carbonate preservation with periods on the order of 40 k.y. Variations in percent resistant species (RSP) and percent carbonate downcore are significantly less correlated to percent whole foraminifers than they are to percent whole foraminifers in modern tropical Atlantic and Ceara Rise sediments. This suggests that changes in carbonate preservation at Site 927 are best reflected by downcore variations in percent whole foraminifers and that both percent carbonate and percent RSP exhibit variability not exclusively related to changes in preservation. Many downcore percent whole foraminifer values, especially from samples deposited during glacial maxima, fall below values typical of well-preserved supra-lysoclinal modern tropical Atlantic sediments and identify intervals in Site 927 that were probably affected by differential dissolution.

The 15 most abundant species exhibit considerable variability downcore. Patterns of variability for important species are not highly correlated, nor do they seem to be related in a simple manner to $\delta^{18} \mathrm{O}$ defined glacial/interglacial cycles. The four most abundant species (Globigerinoides ruber, G. sacculifer, Globigerinita glutinata, and Neogloboquadrina dutertrei) exhibit high frequency fluctuations ( $1 / \mathrm{f}$ on the order of $10^{4} \mathrm{yr}$ ) with amplitudes of $10 \%-20 \%$. A number of important species (e.g., Globorotalia menardii, Pulleniatina obliquiloculata, Globigerina rubescens, and Globorotalia truncatulinoides [left coiling]) are absent or occur in trace amounts over long intervals that alternate with intervals of much higher average abundance and high frequency variability. A comparison of foraminifer faunal variation with carbonate preservation suggests that faunal variability is decoupled from changes in preservation. Thus, much of the faunal variability is likely associated with changes in the environmental conditions of Ceara Rise surface waters.

Downcore faunas were compared to modern faunas using the Modern Analog Technique (MAT). The MAT was also used to compare downcore faunas to modern Ceara Rise faunas. Foraminifer faunas were most similar to modern Ceara Rise faunas during isotope Stage 21 and, to a lesser extent, Stages 19 and 17. Finally, the MAT was used to estimate downcore cold-season and warm-season sea surface temperatures (SST). SST estimates show little variability and suggest that the significant faunal variability observed between 1000 and $500 \mathrm{ka}$ is related to surface water changes other than SST. Comparison with foraminifer faunal variability in modern tropical Atlantic sediments suggests that the observed downcore species variability may be related to changes in the mixed layer depth and the amount of time the thermocline is in the photic zone during the annual cycle. In general, "mixed layer" species (G. ruber, G. glutinata, and G. sacculifer) are most abundant during interglacials, whereas "thermocline" species (G. menardii, P. obliquiloculata, N. dutertrei, and Globorotalia tumida) are most abundant during glacial intervals when conditions in the surface waters may have been more similar to conditions found farther east in the present-day tropical Atlantic where surface sediments are richer in "thermocline" species. These interpretations, however, cannot easily explain the numerous large-scale and abrupt downcore changes in relative abundances observed for many species.
\end{abstract}

\section{INTRODUCTION}

During Leg 154 of the Ocean Drilling Program (ODP), a series of holes were successfully drilled from a tightly spaced transect of five sites on the Ceara Rise in the western equatorial Atlantic Ocean. Closely spaced, shipboard measurements of magnetic susceptibility,

${ }^{1}$ Shackleton, N.J., Curry, W.B., Richter, C., and Bralower, T.J. (Eds.), 1997. Proc. ODP, Sci. Results, 154: College Station, TX (Ocean Drilling Program).

${ }^{2}$ Department of Geological Sciences, Salem State College, Salem, MA 01970, U.S.A.CULLEN@dgl.ssc.mass.edu

${ }^{3}$ Department of Geology and Geophysics, Woods Hole Oceanographic Institution, Woods Hole, MA 02543, U.S.A. natural gamma emission, and color reflectance documented the complete recovery of overlapping, triple advanced hydraulic piston cored (APC) intervals at all five sites. These data were used to produce composite sedimentary sequences spanning the last 7-8 m.y. A major thrust of post cruise research has focused on late Neogene, high resolution paleoceanographic reconstructions of deep-water circulation, the history of changes in the western tropical Atlantic surface water conditions, including carbonate production, and the history of carbonate dissolution. The two shallowest sites along the depth transect, Site 925 (water depth $=3041 \mathrm{~m}$ ) and Site 927 (water depth $=3315$ $\mathrm{m}$ ), are well above the modern lysocline and contain relatively wellpreserved planktonic foraminifer faunas, which makes them particularly well-suited for documenting changes in surface-water conditions. 
Documenting changes in surface-water conditions above the Ceara Rise is important for a number of reasons.

1. The Ceara Rise underlies surface waters that exhibit high temperatures (greater than $27^{\circ} \mathrm{C}$ ) with little annual variability. Results from CLIMAP Project Members $(1976,1981)$ suggest that western tropical Atlantic surface water temperatures change little on glacial/interglacial time scales. The relatively warm western tropical Atlantic, along with similarly warm western tropical surface water masses in the Pacific and Indian Oceans, is important in modeling past atmospheric circulation. The late Pleistocene temporal stability of these warm water pools is presently being actively debated.

2. The area should be well suited for reconstructing the history of surface temperature conditions caused more by global rather than local changes in climate because it is located on the western side of the Atlantic where surface water temperature should be minimally affected by local changes in upwelling.

3. The effects of dissolution on carbonate accumulation and foraminifer fluxes in deeper sites can then be interpreted within the context of changes in carbonate accumulation and foraminifer fluxes caused by changes in surface water conditions.

Here, we focus on generating a high resolution time series of surface water and carbonate preservation variability for the middle Pleistocene (500-1000 ka) using closely spaced samples from the Site 927 composite sediment section. Of the two shallow sites, Site 927 was chosen because its middle Pleistocene to Holocene accumulation rate, at $4.3 \mathrm{~cm} / 1000 \mathrm{yr}$, is no less than $25 \%$ higher than the rate at Site 925 . In addition, Site 927 is in close proximity to the two deepest, presumably more dissolution sensitive sites in the depth transect (Sites 928 and 929; Fig. 1). The higher accumulation rate for Site 927 is due to its more northern location and closer proximity to the Amazon River mouth, which results in greater input of noncarbonate sediments to the northern flank of the Ceara Rise.

The Site 927 composite section was sampled between 23 and 43 meters composite depth (mcd) at $10-\mathrm{cm}$ spacing (equivalent to around a 2300-yr sample spacing) to produce records of changing planktonic foraminifer composition, changing carbonate preservation, changing calcium carbonate and coarse fraction $(>63 \mu \mathrm{m})$ content, and changing $\delta^{18} \mathrm{O}$ and $\delta^{13} \mathrm{C}$ content of Globigerinoides sacculifer. Specifically, these records are used to (1) document downcore variations in the relative abundances of planktonic foraminifer species; (2) document variations in foraminifer preservation using faunal dissolution indexes, calcium carbonate, and coarse fraction; (3) investigate the extent that faunal variation is related to changing surface water conditions and/or influenced by differential dissolution; (4) establish a glacial/interglacial time-stratigraphic framework for Site 927 using the G. sacculifer $\delta^{18} \mathrm{O}$ record and use the $\delta^{18} \mathrm{O}$ stratigraphy to check the top-most (last 1 m.y.) part of the chronology developed for Site 927 by Bickert et al. (Chapter 15, this volume); (5) use the foraminifer faunas to reconstruct changes in sea surface temperature (SST) in the western tropical Atlantic between 500 and 1000 ka using the Modern Analog Technique (Prell, 1985); (6) examine faunal, SST, and preservation changes in the time domain during the middle Pleistocene; and (7) preliminarily interpret downcore faunal changes in terms of changes in the hydrography of the surface water layer above the Ceara Rise.

\section{DEPOSITIONAL SETTING}

Site 927 was drilled on a 3315-m-deep plateau located on the northeastern flank of the Ceara Rise. The uppermost $312 \mathrm{~m}$ of the approximately $1.2-\mathrm{km}$-thick sedimentary section was continuously cored with the APC in three holes (927A, 927B, and 927C). The up-

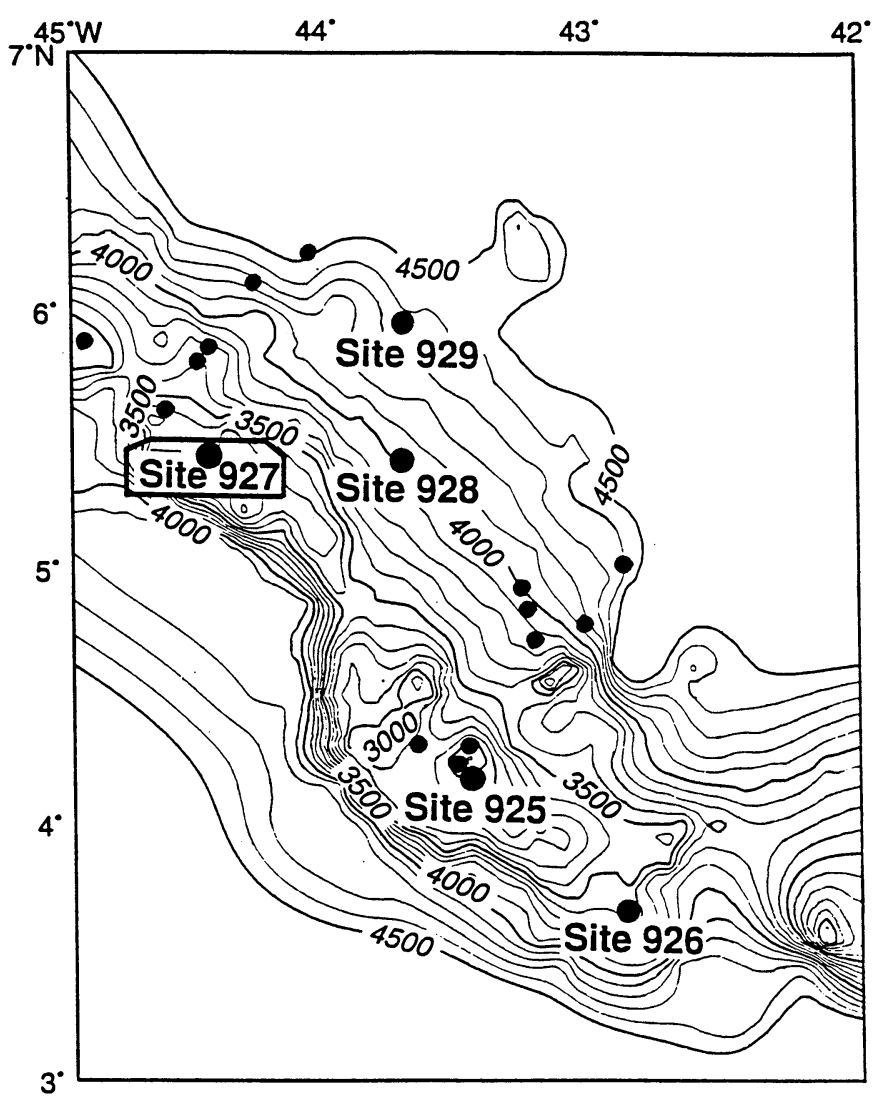

Figure 1. Map location of Leg 154 drilling sites, including Site 927. Unlabeled dots are locations of Ceara Rise surface sediment samples analyzed for this study (see text).

permost $152 \mathrm{~m}$ of the sedimentary section consists of a single lithologic unit consisting of clayey nannofossil ooze and nannofossil clay (Curry, Shackleton, Richter, et al., 1995).

\section{SAMPLING}

A composite depth section was constructed for Site 927 using closely spaced magnetic susceptibility and color reflectance measurements from the three holes (see Curry, Shackleton, Richter, et al., 1995). A single spliced record for coordinated sampling was subsequently assembled from aligned cores in the three holes. In all, we collected and processed $43510-\mathrm{cm}^{3}$ samples at approximately $10-\mathrm{cm}$ spacing over the top $43 \mathrm{mcd}$ of the Site 927 splice. Here we report analyses from the 200 samples collected between 23 and 43 mcd.

\section{SAMPLE PROCESSING AND ANALYSIS}

All but a small volume of each sample was dry-weighed, disaggregated in tap water, and subsequently wet-sieved through a $63-\mu \mathrm{m}$ screen. Dry coarse fraction $(>63 \mu \mathrm{m})$ residues were weighed and sieved through a $150-\mu \mathrm{m}$ screen. The $>150-\mu \mathrm{m}$ size fraction was also weighed and split in half, and aliquots of this material containing an average of 323 whole specimens of planktonic foraminifers per sample were prepared. For each sample aliquot, we recorded specimen counts of each planktonic foraminifer species and the total planktonic foraminifer fragments. 
Table 1. Planktonic foraminifer taxonomic categories used in the present study along with their means, standard deviations, and minimum and maximum occurrences between 23 and 43 mcd in Site 927.

\begin{tabular}{|c|c|c|c|c|c|}
\hline Planktonic foraminifer species & $\begin{array}{l}\text { Species } \\
\text { code }\end{array}$ & $\begin{array}{c}\text { Mean } \\
\text { (relative \%) }\end{array}$ & $\begin{array}{c}\mathrm{SD} \\
\text { (relative \%) }\end{array}$ & $\begin{array}{c}\text { Minimum } \\
\text { (relative \%) }\end{array}$ & $\begin{array}{c}\text { Maximum } \\
\text { (relative \%) }\end{array}$ \\
\hline Globigerinoides ruber (d'Orbigny) & truber & $32.6(35.6)$ & 8.6 & 7.9 & 58.1 \\
\hline Globigerinoides sacculifer (d'Orbigny) & tsacc & $15.9(17.0)$ & 6.3 & 2.2 & 36.5 \\
\hline Globigerinita glutinata (Egger) & glut & $9.8(6.8)$ & 5.4 & 0 & 25.4 \\
\hline Neogloboquadrina dutertrei (d'Orbigny) & dutr & $9.1(6.8)$ & 6.1 & 1.0 & 32.3 \\
\hline *Globorotalia menardii (d'Orbigny) & men & $4.9(6.8)$ & 5.7 & 0 & 21.6 \\
\hline *Pulleniatina obliquiloculata (Parker and Jones) & obliq & $4.7(3.2)$ & 5.0 & 0 & 28.5 \\
\hline Globigerina rubescens Hofker & rubsc & 3.7 & 4.3 & 0 & 23.9 \\
\hline *Neogloboquadrina pachyderma (Ehrenberg), right coiling & pachyr & $2.2(2.6)$ & 3.5 & 0 & 24.5 \\
\hline Globigerina falconensis Blow & falc & 2.0 & 1.9 & 0 & 11.6 \\
\hline Globigerinella aequilateralis (Brady) & aequ & $1.8(3.7)$ & 1.5 & 0 & 8.3 \\
\hline *Globorotalia truncatulinoides (d'Orbigny), right coiling & truncr & 1.4 & 2.7 & 0 & 8.9 \\
\hline * Globorotalia truncatulinoides (d'Orbigny), left coiling & truncl & 1.4 & 2.7 & 0 & 12.9 \\
\hline Globigerinoides tenellus Parker & tene & 1.4 & 2.0 & 0 & 12.1 \\
\hline *Globorotalia crassaformis (Galloway and Wissler) & crass & 0.9 & 1.5 & 0 & 11.8 \\
\hline Globigerina bulloides d'Orbigny & bull & 0.9 & 1.0 & 0 & 5.7 \\
\hline Globigerina calida Parker & cali & 0.8 & 0.7 & 0 & 2.8 \\
\hline Globigerinoides conglobatus (Brady) & congl & 0.8 & 1.1 & 0 & 6.8 \\
\hline Globorotalia scitula (Brady) & scit & 0.7 & 0.8 & 0 & 5.5 \\
\hline Orbulina universa d'Orbigny & univ & 0.7 & 0.6 & 0 & 2.8 \\
\hline * Globorotalia tumida (Brady) & tum & $0.6(4.1)$ & 0.9 & 0 & 3.8 \\
\hline *Sphaeroidinella dehiscens (Parker \& Jones) & dehi & 0.3 & 0.5 & 0 & 2.8 \\
\hline Globorotalia inflata (d'Orbigny) & infl & $0.3(2.8)$ & 0.7 & 0 & 5.7 \\
\hline Globoquadrina hexagona (Natland) & hexa & 0.3 & 0.6 & 0 & 3.3 \\
\hline Globigerina digitata Brady & digi & 0.3 & 0.4 & 0 & 1.8 \\
\hline Globorotalia theyeri Fleisher & they & 0 & 0.2 & 0 & 1.6 \\
\hline Globorotalia hirsuta (d'Orbigny) & hirs & 0 & 0.1 & 0 & 0.7 \\
\hline Candeina nitida d'Orbigny & niti & 0 & 0.1 & 0 & 1.3 \\
\hline Globoquadrina conglomerata (Schwager) & conglm & 0 & 0.1 & 0 & 0.6 \\
\hline *Neogloboquadrina pachyderma (Ehrenberg), left coiling & pachyl & 0 & 0.1 & 0 & 0.9 \\
\hline Globorotalia anfracta Parker & anfr & 0 & 0 & 0 & 0.3 \\
\hline Globigerina quinqueloba Natland & quin & 0 & 0 & 0 & 0.3 \\
\hline Globorotalia crassula (Cushman \& Stewart) & crassu & 0 & 0 & 0 & 0.4 \\
\hline * Globorotalia menardii neoflexuosa Srinivasan, Kennett, and Bé & menflx & 0 & 0 & 0 & 0.3 \\
\hline *Resistant species & $\%$ RSP & $25.8(29.0)$ & 11.5 & 7.6 & 66.5 \\
\hline
\end{tabular}

Notes: Number of samples (NS) $=200$. Values in parentheses in the mean column are the mean relative abundances for all species from tropical Atlantic surface sediments $($ NS $=118$ ) whose mean abundance exceeds $1.5 \%$. SD = standard deviation.

Planktonic foraminifer species identifications are consistent with the taxonomy used in Cullen and Prell (1984) with the following changes. (1) The "pachyderma-dutertrei intergrade" category has been eliminated. Specimens previously included in this artificial category are now placed in either $N$. dutertrei or Neogloboquadrina pachyderma (right coiling) according to a set of morphologic criteria defined while refining taxonomic categories for our Global Data Base Project (Cullen et al., unpubl. data); and (2) the taxonomic categories Globorotalia anfracta Parker and Globorotalia crassula (Cushman and Stewart) have been added. All taxonomic categories are listed in Table 1.

\section{DATA}

To achieve the goals of this study, three sets of downcore data were generated: (1) relative abundance data for planktonic foraminifer species, (2) carbonate preservation data (dissolution data), and (3) stable isotope data. (All data can be found as an Appendix to this chapter on the CD-ROM, back pocket, this volume.)

\section{Planktonic Foraminifer Faunal Data}

At least one specimen from each of 33 different taxonomic categories was recorded in at least one of the 200 samples analyzed between 23 and 43 mcd of Site 927. Downcore faunas are dominated by nine species that constitute nearly $85 \%$ of the average species population. In total, 18 species have maximum relative abundances that exceed $5 \%$. The total faunal data is statistically summarized in Table 1. Downcore variations of important species are presented in Figure 2.

\section{Preservation Data}

We calculated two indicators of relative carbonate preservation from the $>150-\mu \mathrm{m}$ size fraction: (1) planktonic foraminifer fragmentation expressed as percent whole foraminifers, which equals $100 \times$ number of whole foraminifer tests / (number of whole tests + number of fragments) and (2) percent resistant species (RSP). Dissolution RSP are identified with an asterisk in Table 1 and are similar to those used in Berger (1975) and Cullen (1981). These indicators have been widely used to assess the preservational state of calcite in a sample and to assess the extent to which the differential dissolution of foraminifer species has modified the original faunal composition of a sample (e.g., Berger et al., 1982; Cullen, 1985; Cullen and Prell, 1984; Cullen and Droxler, 1990; Chen and Farrell, 1991; Le and Shackleton, 1992). In addition, we calculated the percent coarse fraction $(>63 \mu \mathrm{m})$ of each sample and measured the percent calcium carbonate content of each sample using the technique described in Curry and Cullen (this volume). Both of these variables have also been widely used as proxy indicators of relative dissolution intensity and the preservational state of deep-sea carbonate (e.g., Berger, 1970; Berger et al., 1982; Curry and Lohman, 1985, 1986; Peterson and Prell, 1985; Farrell and Prell, 1989, 1991; and the extensive reference lists contained in these publications). Each indicator is statistically summarized in Table 2. Downcore variations in these indicators are presented in Figure 3.

\section{Stable Isotope Data}

The oxygen and carbon isotopic composition of sized (300-355 $\mu \mathrm{m})$ specimens of Globigerinoides sacculifer were analyzed at 10$\mathrm{cm}$ spacing over the top $43 \mathrm{mcd}$ of Site 927 . The analytical procedure 
Figure 2. Downcore variations in the percent relative abundances of the 17 most important species of planktonic foraminifers between 23 and $43 \mathrm{mcd}$ at Site 927. A. Downcore variations in percent relative abundance of G. ruber, G. sacculifer, G. glutinata, and $N$. dutertrei. B. Downcore variations in percent relative abundance of G. menardii, P. obliquiloculata, $G$. rubescens, and $N$. pachyderma (right coiling). C. Downcore variations in percent relative abundance of G. tenellus, G. falconensis, G. aequilateralis, and $G$. truncatulinoides, right coiling. D. Downcore variations in relative abundances of G. tumida, G. truncatulinoides (left coiling), G. crassaformis, $G$. conglobatus, and G. bulloides.
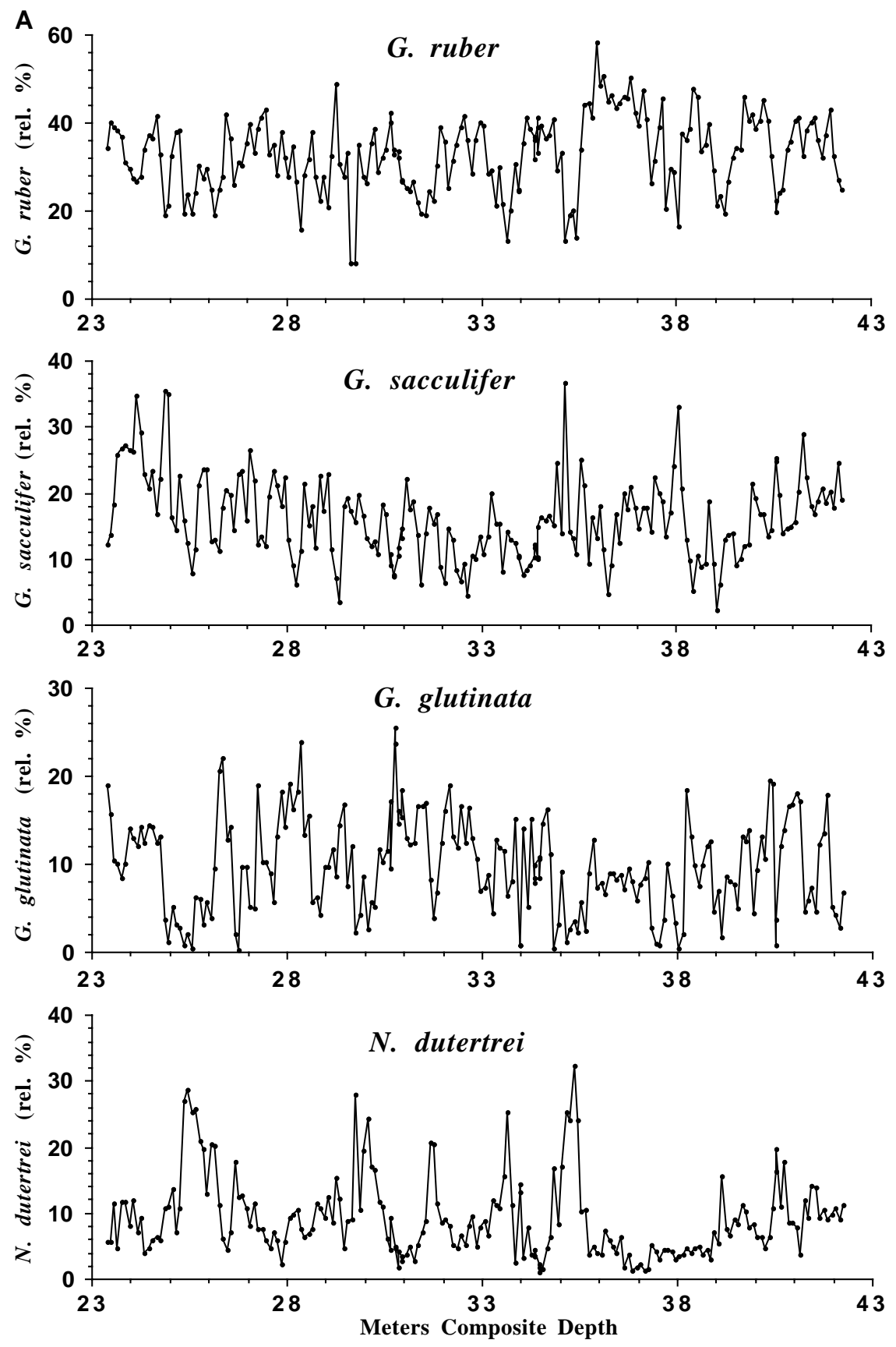

is discussed in Curry and Cullen (this volume). All values are reported in per million $(\% \circ)$ difference relative to the Peedee belemnite (PDB) standard (Craig, 1957). The oxygen isotope data from 435 samples were used to establish a glacial/interglacial time-stratigraphic framework and to check the upper $1 \mathrm{~m}$.y. section of the chronology developed by Bickert et al. (Chapter 15, this volume). Results are presented in Figure 4 and are discussed in more detail below.

\section{RESULTS}

\section{Isotope Stratigraphy}

We compared the isotope record in Figure 4A with the composite $\delta^{18} \mathrm{O}$ record from Prell et al. (1986) and assigned isotope stages to our record down to Stage 20. Beyond that, we compared our record to the Site 607 record in Raymo et al. (1990) and have unambiguously assigned isotope stages down to interglacial Stage 27 (Fig. 4A). Thus, we can evaluate downcore faunal and carbonate preservation records within the context of glacial/interglacial climatic cycles over the 23 to 43 mcd interval in Site 927 (from isotope Stages 13 to 28).

To be consistent with other Leg 154 high resolution late Neogene studies in this volume, we use the chronology developed by Bickert et al. (Chapter 15, this volume) for Site 927 over the past 2.5 m.y. that is independent of the $\delta^{18} \mathrm{O}$ data presented here. It is a tuned time scale based on the high resolution magnetic susceptibility data from Site 927 tuned to the precessional cycle using a 2 k.y. lag for magnetic susceptibility. The 1-m.y. time series of $\delta^{18} \mathrm{O}$ variations presented in Figure 4B was generated using this chronology. The resulting ages 

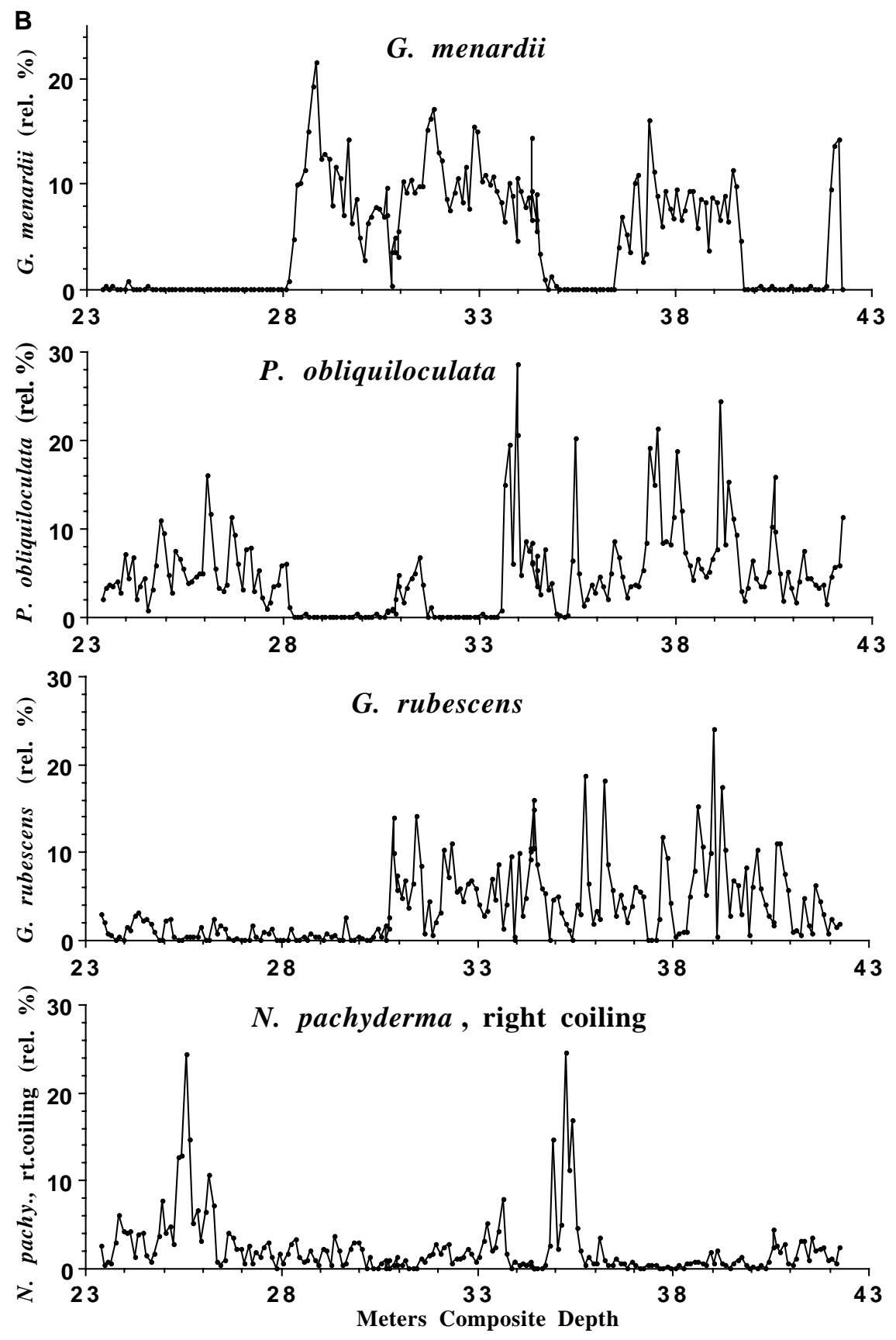

Figure 2 (continued).

for a randomly chosen series of specific isotopic events are in excellent agreement with the ages of corresponding composite isotopic events derived from the orbitally tuned $780 \mathrm{k} . \mathrm{y} . \delta^{18} \mathrm{O}$ chronology in Imbrie et al. (1984).

\section{Preservation}

The downcore records of percent whole foraminifers, percent RSP, percent calcium carbonate, and percent coarse fraction are shown in Figure 3. Despite the fact that all of these variables have been widely used to evaluate relative amounts of carbonate dissolution and the extent to which differential dissolution may have modi- fied the foraminifer species composition of sediment samples (see references in "Preservation Data" section above), not all of the observed variance in each of the records will be related to carbonate dissolution/preservation. Each dissolution indicator, to varying degrees, is affected by processes not associated with dissolution. For example, even though percent carbonate and percent coarse fraction values will decrease with increasing carbonate dissolution, terrigenous dilution can also reduce their relative abundances. Percent RSP values will increase with increasing carbonate dissolution, but can also be influenced by changes in the original faunal composition of samples, as can (although to a lesser extent) percent whole foraminifers, which will nonlinearly decrease with increasing carbonate dissolution. Such 
Figure 2 (continued).
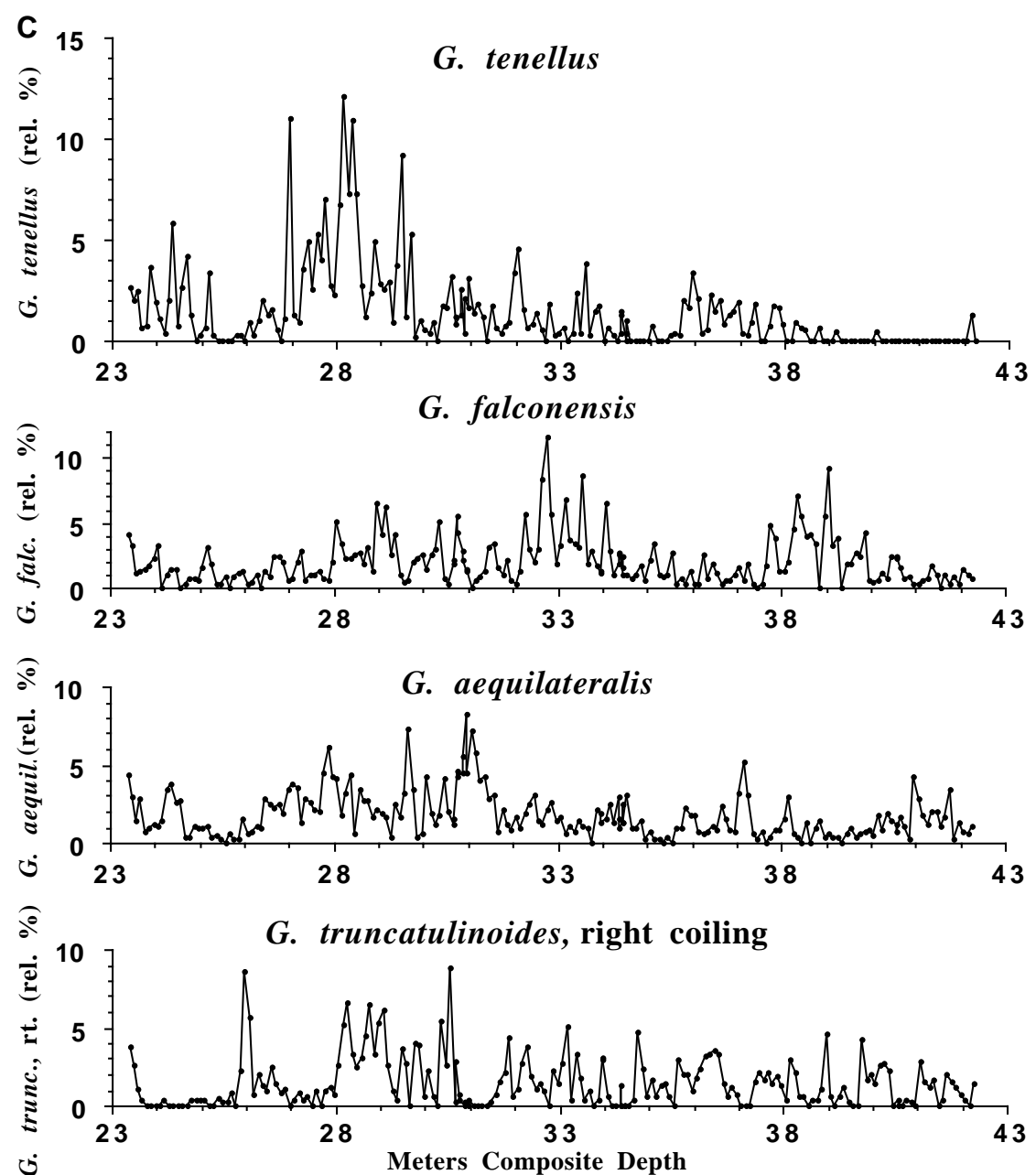

non-dissolution related processes can reduce the degree of intercorrelation between the various dissolution indicators within a particular data set (see correlation matrix in Table 2).

To more fully evaluate the preservation data at Site 927, and to help us determine which dissolution indicator is most likely responsive to dissolution in downcore sediments at Site 927, we examined the depth distribution of percent whole foraminifers, percent RSP, and percent calcium carbonate from 14 modern surface sediment samples from the Ceara Rise (Fig. 5; core top locations are shown on Fig. 1), as well as percent whole foraminifers and percent RSP from 118 modern surface sediment samples from the tropical Atlantic Ocean (Fig. 6). The tropical Atlantic plots reveal an average position for the foraminiferal lysocline (FL) between 4100 and $4200 \mathrm{~m}$ water depth as indicated by the abrupt increase in percent RSP and foraminifer fragmentation (expressed here as the abrupt decrease in percent whole foraminifers) at this depth level. Samples shallower than 4000 $\mathrm{m}$ exhibit little or no depth-related change in either preservation indicator. RSP values remain below about $30 \%$ in water depths above the FL and percent whole foraminifer values generally remain above about $70 \%$ at water depths above the FL. Note that some sediments from above the FL contain considerable fragments (Fig. 6). The open circles on the percent whole foraminifers plot represent shallow surface sediment samples with high fragmentation (expressed as low percent whole foraminifer values) located below the more productive waters of coastal upwelling regions or are shallow samples adjacent to continental margins (only four of these 23 samples contain $>30 \%$ RSP).
The Ceara Rise percent whole foraminifers and percent $\mathrm{CaCO}_{3}$ depth plots (Fig. 5) indicate a local FL at around $4200 \mathrm{~m}$ (within the depth interval for the mixing zone between northern-source deep water, NADW, and southern-source deep water, AABW). Samples above the FL consistently contain $>80 \%$ whole foraminifers and $>60 \% \mathrm{CaCO}_{3}$. In the present-day Ceara Rise area, samples that exhibit high fragmentation (percent whole foraminifer values below 30\%) do not seem to contain appreciable amounts of resistant species $(<20 \%)$. Finally, there is a high linear correlation between carbonate content and percent whole foraminifers $(r=+0.86)$ in modern Ceara Rise sediments.

Reexamination of the downcore plots of percent whole foraminifers and percent RSP reveals numerous intervals with preservation values well out of the present-day ranges exhibited above the FL in the tropical Atlantic Ocean suggesting that these intervals exhibit levels of preservation similar to present-day sediments from below the FL, despite the fact that Site 927 is nearly $1000 \mathrm{~m}$ above the modern local FL. The entire downcore interval exhibits carbonate values below those observed above the FL in the present-day Ceara Rise region. The average percent carbonate in several well-preserved downcore intervals (as indicated by very high percent whole foraminifer values) is highly variable, with some intervals as low as $35 \%$ carbonate and others as high as 55\% carbonate. In addition, percent carbonate within any one of the well-preserved intervals exhibits ranges as high as $30 \%$. The degree of correlation between percent whole foraminifers and percent carbonate in Site 927 sediments is considerably less $(r=+0.60)$ than that observed in present-day Ceara Rise sedi- 

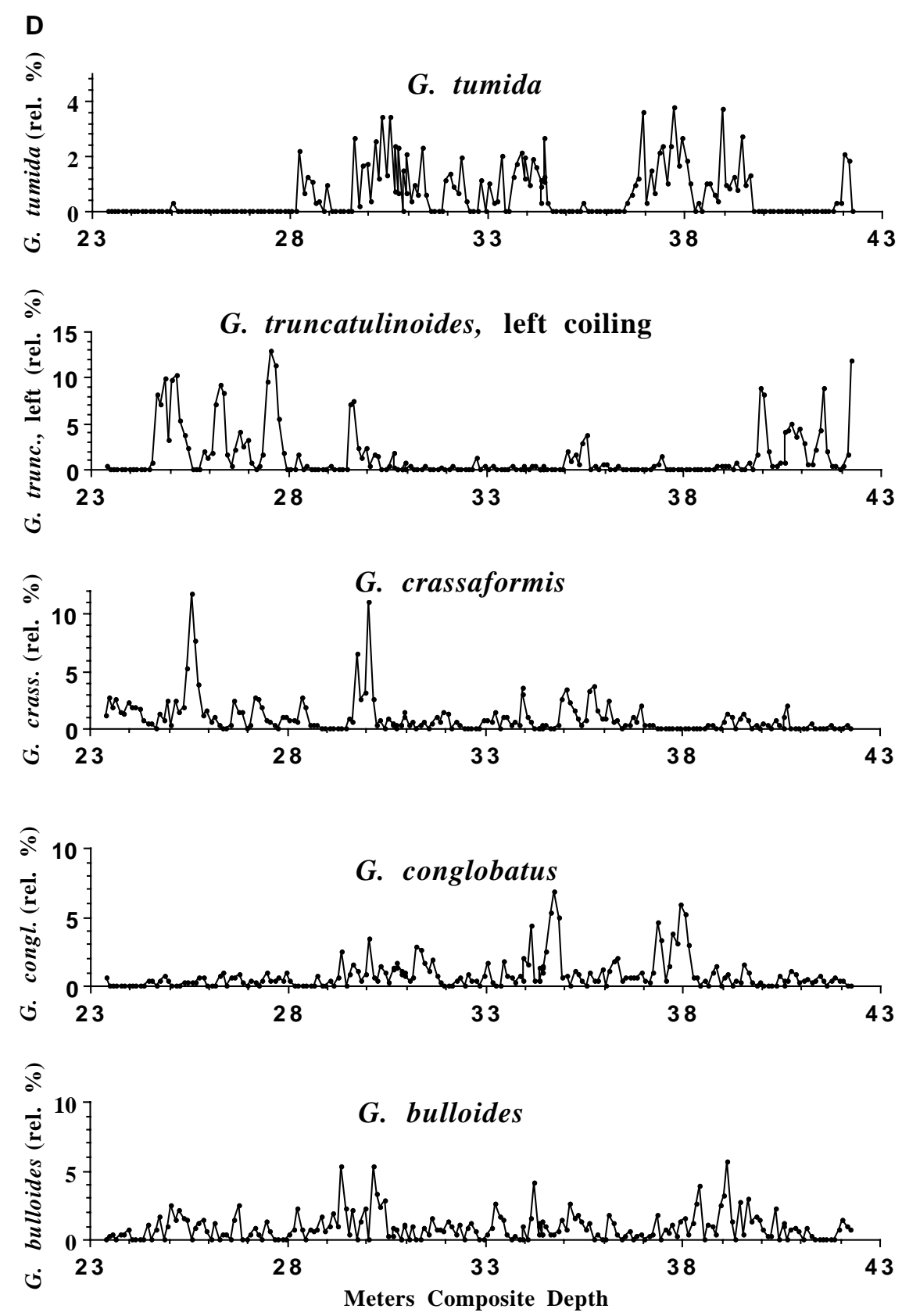

Figure 2 (continued).

Table 2. Various indicators of carbonate preservation between 23 and 43 mcd in Site 927.

\begin{tabular}{|c|c|c|c|c|c|c|c|}
\hline \multirow[b]{2}{*}{ Preservation indicator } & \multirow{2}{*}{$\begin{array}{c}\text { Mean* } \\
\text { (relative \%) }\end{array}$} & \multirow[b]{2}{*}{$\mathrm{SD}^{*}$} & \multirow{2}{*}{$\begin{array}{l}\text { Minimum } \\
\text { (relative \%) }\end{array}$} & \multirow{2}{*}{$\begin{array}{l}\text { Maximum } \\
\text { (relative \%) }\end{array}$} & \multicolumn{3}{|c|}{$\begin{array}{l}\text { Correlation coefficients } \\
\text { (foraminifers)* }\end{array}$} \\
\hline & & & & & $\%$ Whole & $\%$ RSP & $\% \mathrm{CaCO}_{3}$ \\
\hline$\%$ Whole foraminifers & & 21.4 & 18.4 & 96.7 & & & \\
\hline \% Resistant species (RSP) & 25.8 & 11.5 & 7.6 & 66.5 & -0.59 & & \\
\hline$\% \mathrm{CaCO}_{3}$ & 29.6 & 10.4 & 3.4 & 60.0 & +0.60 & -0.60 & \\
\hline$\%$ Coarse fraction $(>63 \mu \mathrm{m})$ & 8.2 & 5.3 & 0.9 & 28.1 & +0.63 & -0.60 & +0.84 \\
\hline
\end{tabular}

Note: $*$ Number of samples $=200, \mathrm{SD}=$ standard deviation. 
Figure 3. Downcore variations in carbonate preservation indicators between 23 and $43 \mathrm{mcd}$ in Site 927, including percent whole foraminifers, percent resistant species (RSP), percent calcium carbonate, and percent coarse fraction ( $>63$ $\mu \mathrm{m})$.
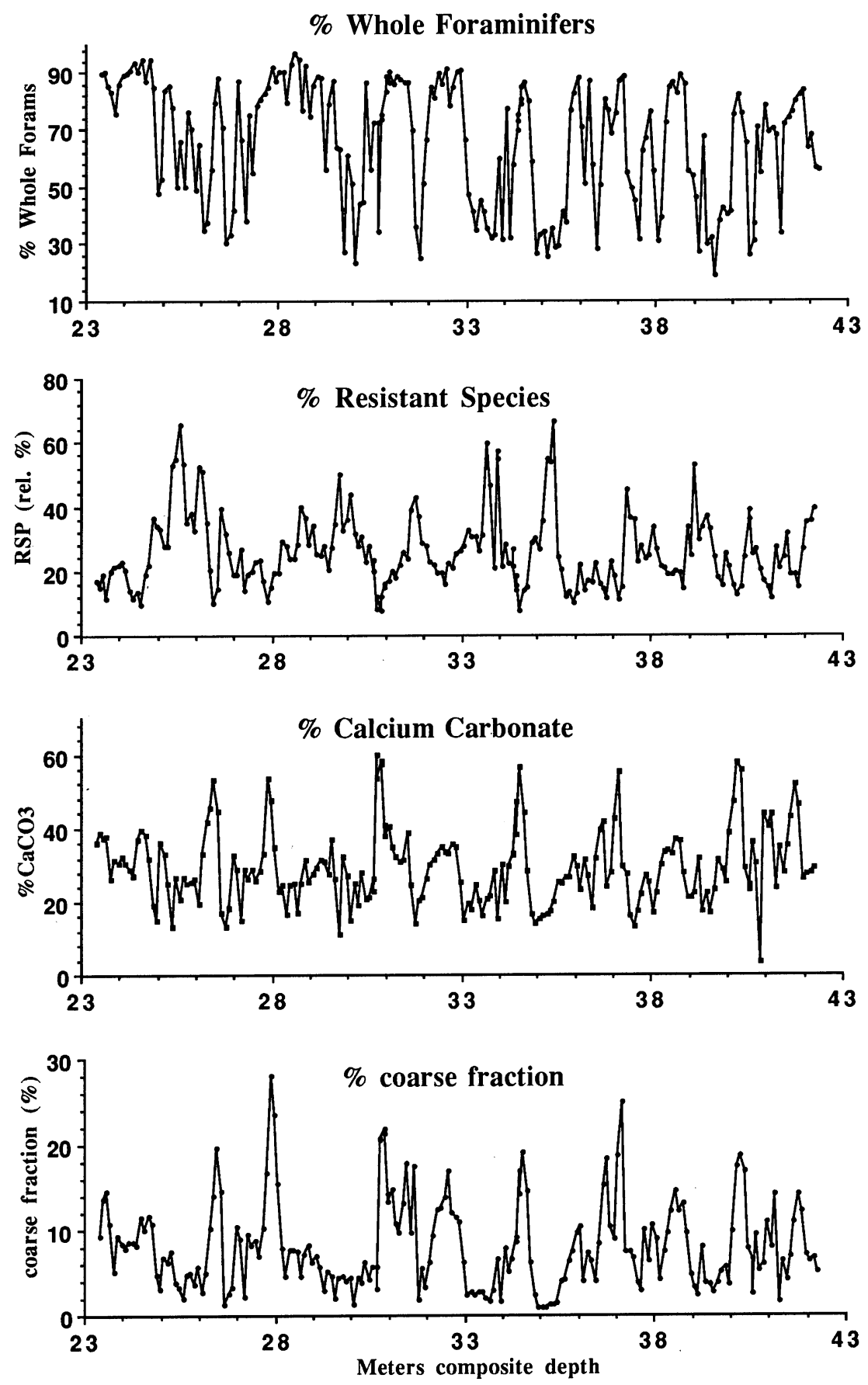

ments $(r=+0.86)$; the degree of correlation between percent whole foraminifers and percent RSP in Site 927 sediments $(r=-0.59)$ is less than that observed in present-day tropical Atlantic Ocean sediments $(r=-0.70)$. These comparisons suggest that percent carbonate fluctuations within the $23-43$ mcd depth interval are not controlled in a simple way by dissolution and that other factors such as terrigenous dilution and carbonate production may be important. Also, percent RSP variations at Site 927 do not seem to be strongly controlled by changes in preservation as recorded by percent whole foraminifers. These observations suggest that Site 927 downcore changes in carbonate preservation are best reflected by the record of changing percent whole foraminifers.
To more fully understand variations in carbonate content and preservation, we generated the time series of percent whole foraminifers and percent calcium carbonate and plotted these beside the time series of oxygen isotope variations (Fig. 7). Examination of these time series indicates that (1) poorly preserved sediments are found during both glacial and interglacial intervals; however, glacial maxima $\left(\delta^{18} \mathrm{O}\right.$ maxima) generally exhibit poorest preservation as indicated by lows in percent whole foraminifers (around 30\%); (2) all but one peak in carbonate abundance (values $>50 \%$ ) occur during or just after rapid glacial/interglacial transitions; (3) intervals of good preservation last around $40 \mathrm{k} . \mathrm{y}$. and are separated by what seem to be abrupt shorter intervals of poorer preservation; and (4) cyclic carbonate fluc- 
A.

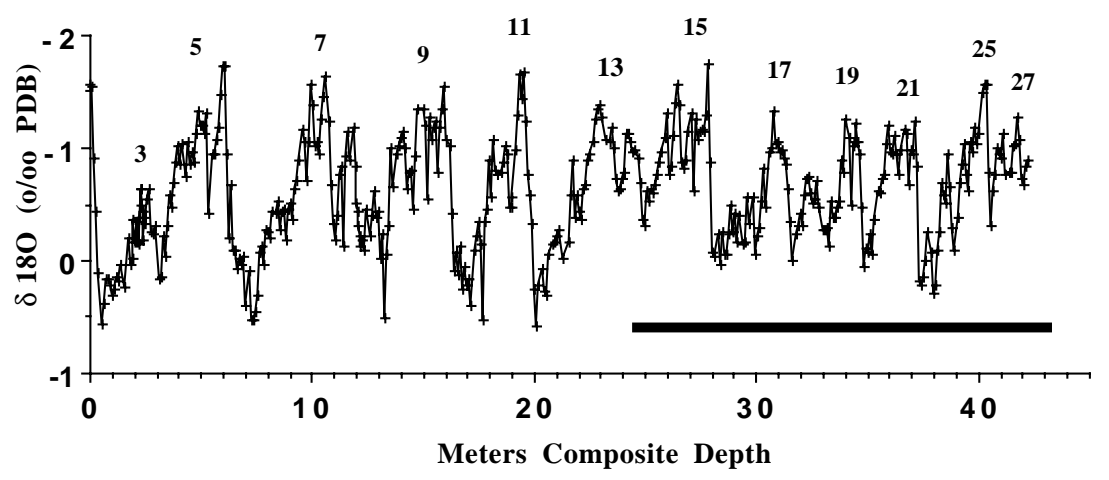

B.

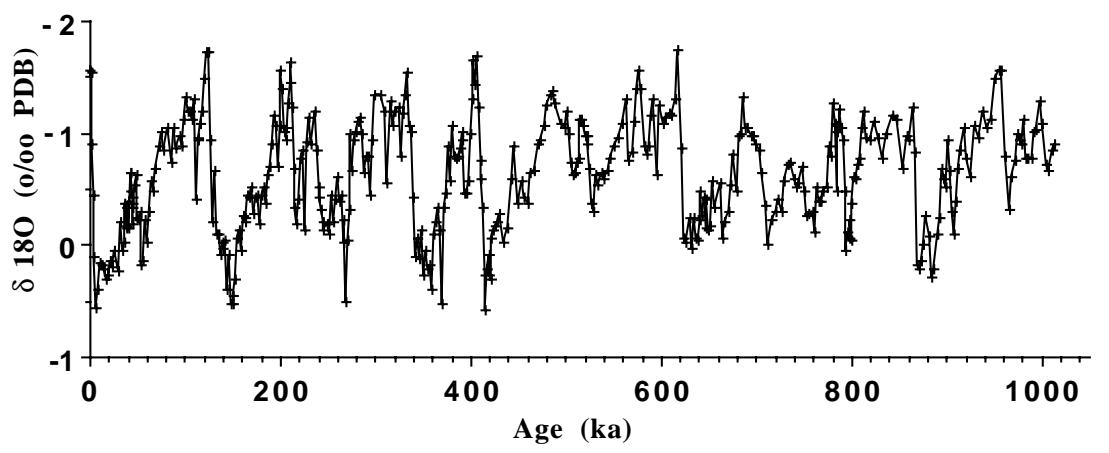

Figure 4. A. Downcore variations in the $\delta^{18} \mathrm{O}$ content (\%o PDB) of sized (300-355 $\mu \mathrm{m})$ specimens of $G$. sacculifer between 0 and $43 \mathrm{mcd}$, Site 927 . Interglacial isotope stages have been numbered. Solid horizontal line identifies the depth interval of Site 927 that has been faunally analyzed. B. Time series of $\delta^{18} \mathrm{O}$ variations using the orbitally tuned chronology of Bickert et al. (Chapter 15, this volume). tuations seem to be occurring roughly every $40 \mathrm{k} . \mathrm{y}$. (12 asymmetrical but distinct carbonate cycles can be identified over the $500 \mathrm{k}$.y. time interval).

In summary, analysis of carbonate abundance and preservation at Site 927 from 23 to 43 mcd (500-1000 ka) indicates that sediments exhibit systematic cyclic changes in preservation and carbonate content and that the downcore variations in preservation indicators are not as highly correlated as they are in tropical Atlantic and Ceara Rise modern sediments. Changes in preservation are best reflected by downcore changes in percent whole foraminifers, while both percent carbonate and percent RSP records exhibit variability that is not related in a simple way to changes in preservation. Many downcore percent whole foraminifer values fall below values typical of wellpreserved modern sediments found above the foraminiferal lysocline in the present-day tropical Atlantic Ocean and identify intervals that have likely been affected to some degree by differential dissolution.

\section{Planktonic Foraminifer Faunas}

Before analyzing the downcore variations in species relative abundances, we compared the average faunal composition in the 2343 mcd interval of Site 927 (Table 1) with the average faunal composition of Holocene surface sediments in the modern tropical Atlantic Ocean presented in Cullen and Prell (1984). The same six species are most abundant in both data sets (see Table 1) and make up $77 \%$ of the average faunal composition in Site 927 and $76 \%$ of the present-day tropical Atlantic, respectively (both data sets contain about the same proportion of samples with percent RSP values $>30 \%$ ).

Examination of Table 1 and Figure 2 reveals that significant downcore variations in foraminifer species relative abundances have occurred at Site 927 over the interval investigated. Fourteen of the 16 most abundant species exhibit ranges at or significantly above $10 \%$.
We closely examined the downcore variability of those 14 plus three other species (Fig. 2). In addition, we generated time series for eight of the most important species and compared each to time series of $\delta^{18} \mathrm{O}$ variations (Fig. 8). Important observations are briefly summarized below.

1. The four most abundant species (Globigerinoides ruber, G. sacculifer, Globigerinita glutinata, and Neogloboquadrina dutertrei; Figs. 2A, 8A) show systematic high-frequency fluctuations with amplitudes predominately in the $10 \%-20 \%$ range. Abrupt larger amplitude abundance changes occur on the transitions between glacials and interglacials. Abundance maxima for G. sacculifer and N. dutertrei, and to a lesser extent $G$. glutinata, seem to occur during glacial maxima. G. ruber is distinctly more abundant during interglacial Stage 21 (around 800-900 ka) and tends to occur at higher average abundances below this interval as well. In contrast, $N$. dutertrei is distinctly less abundant below 36 mcd in sediments older than $800 \mathrm{ka}$. For $G$. sacculifer, the smaller scale fluctuations discussed above seem to be superimposed on a longer term trend in relative abundance (Figs. 2A, $8 \mathrm{~B})$. There is a distinct minimum in this long-term trend at around $750 \mathrm{ka}$ with gradual increases in average relative abundance in the section above and below this interval. This long-term pattern is very similar to the pattern of $\delta^{13} \mathrm{C}$ variation in $G$. sacculifer over the same time interval (Fig. 9). Low G. sacculifer relative abundances seem to correlate with low $\delta^{13} \mathrm{C}$ values.

2. A number of important species, namely Globorotalia menardii, Pulleniatina obliquiloculata, Globigerina rubescens, (Figs. 2B, 8B), and to a lesser extent Globorotalia truncatulinoides (left coiling) and Globorotalia tumida (Figs. 2C, 8C), occur in trace amounts or virtually disappear over long intervals between 23 and 43 mcd at Site 927 and form a significant part of the fluctuating foraminifer faunas between these intervals. The G. menardii complex (G. menardii $+G$. tumida + G. menardii neoflexuosa; Figs. 2B, 8B) is absent in sedi- 
\% Whole Foraminifers

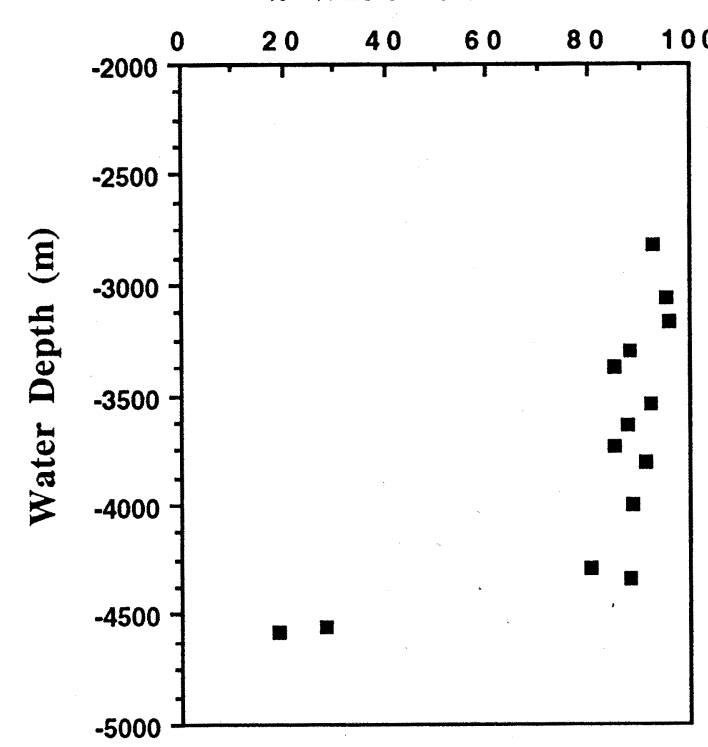

$\%$ Calcium Carbonate

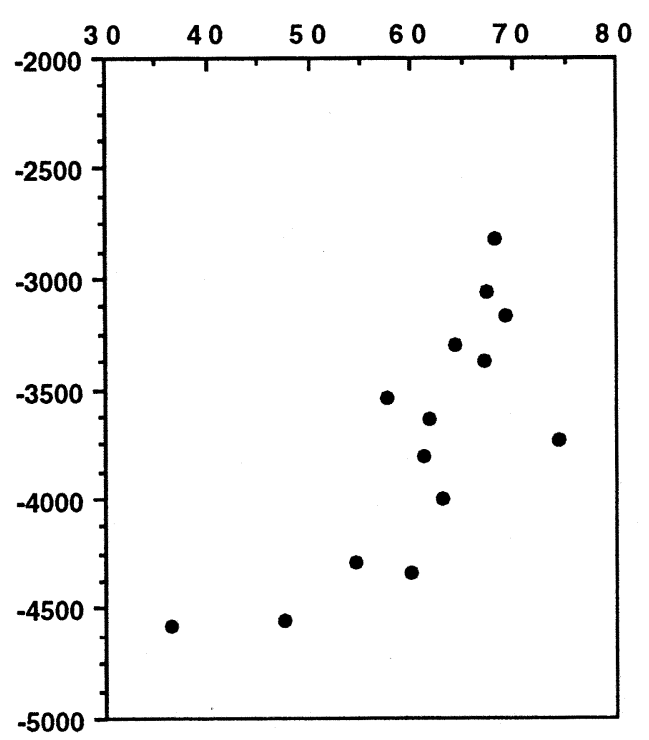

$\%$ Resistant Species

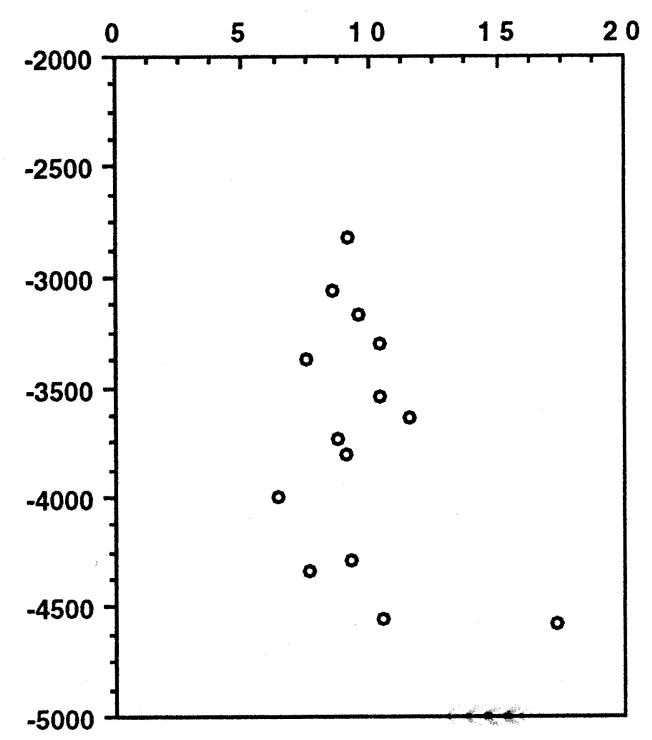

Figure 5. Depth distribution of percent whole foraminifers, percent calcium carbonate, and percent resistant species (RSP) from 14 modern surface sediment samples from the Ceara Rise (see Fig. 1 for sampling locations). 
A

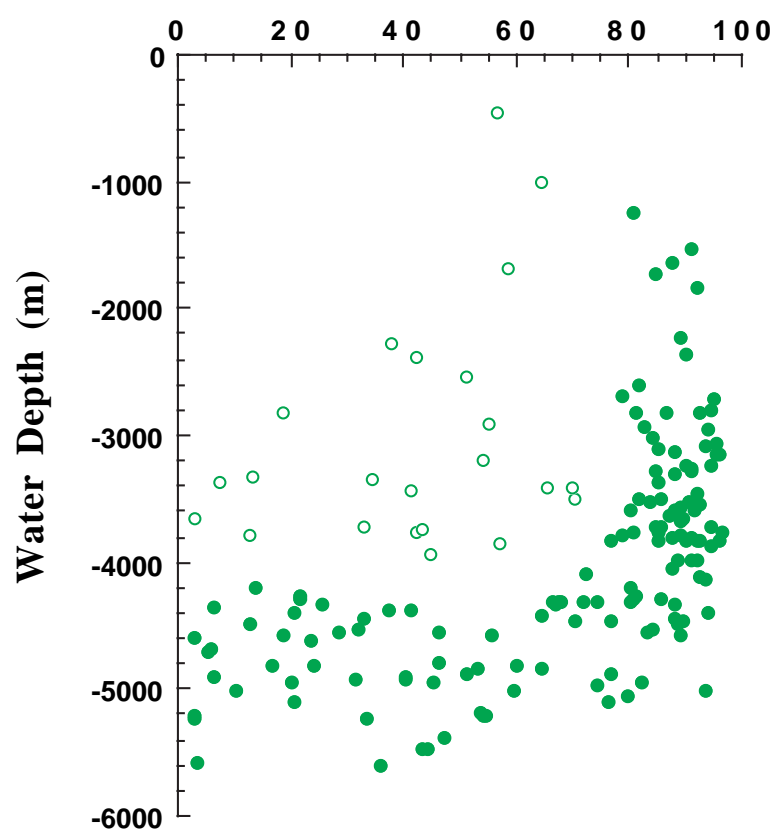

$\%$ Resistant Species

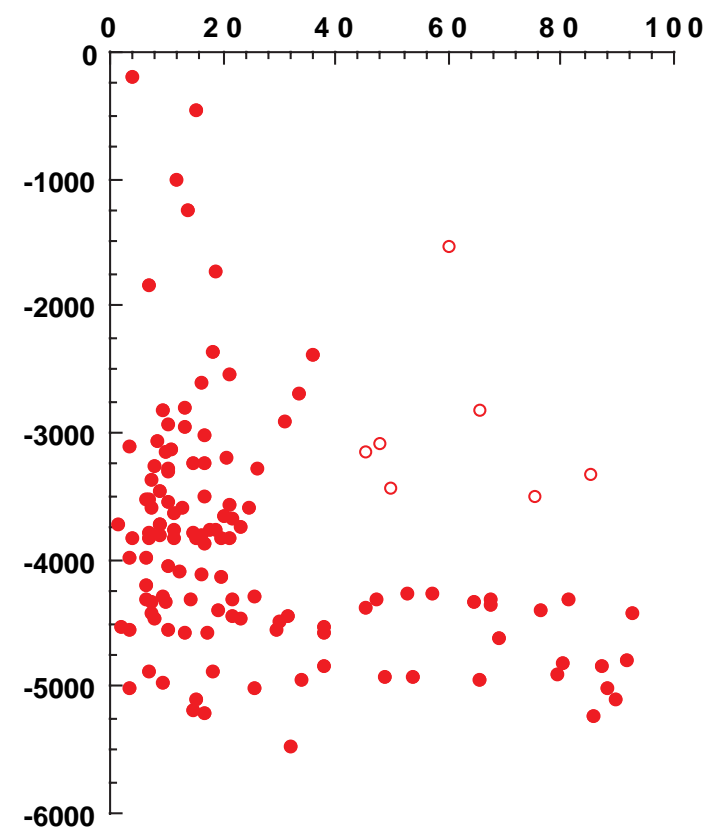

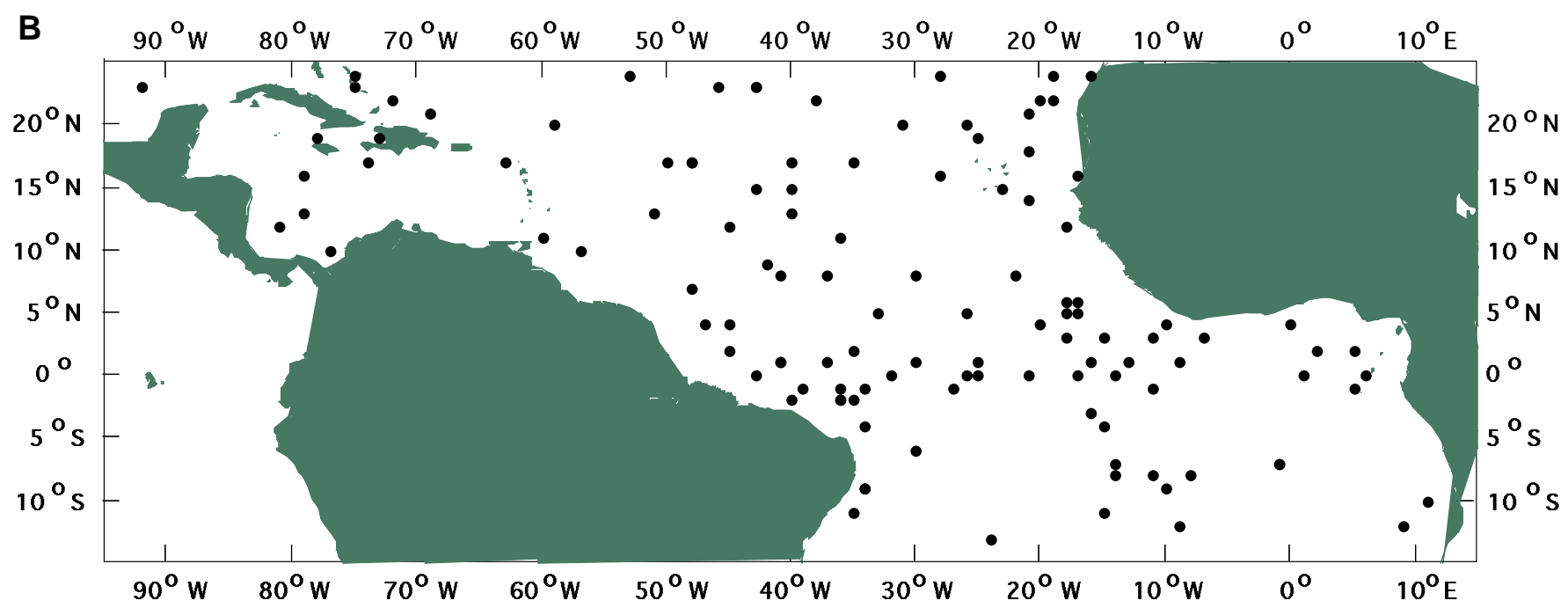

Figure 6. A. Depth distribution of percent whole foraminifers and percent resistant species for 118 surface sediment samples from the tropical Atlantic Ocean. Open circles on percent whole foraminifer depth plot identify surface sediment samples below zones of coastal upwelling and areas near continental margins (see text). B. Map of sampling locations.

ments younger than $630 \mathrm{ka}$ and in sediment between 830 and $790 \mathrm{ka}$ and in sediment between 1000 and $930 \mathrm{ka}$. Note the G. menardii complex remains a significant part of the foraminifer fauna over several glacial/interglacial cycles between 930 and $830 \mathrm{ka}$ and between 790 and $630 \mathrm{ka}$. P. obliquiloculata (Figs. 2B, 8B) abruptly disappears just after reaching its maximum abundances at $750 \mathrm{ka}$ (the isotope Stage $19 / 18$ transition), reappears for a short time in low abundances between 710 and $690 \mathrm{ka}$, and then reappears and remains in appreciable amounts around $630 \mathrm{ka}$. The presence/absence behavior of both the G. menardii complex and P. obliquiloculata in Pleistocene sediments from the tropical Atlantic is expected and has been well documented in many previous studies (e.g., Ericson and Wollin, 1956, 1968; Prell and Damuth, 1978). G. rubescens (Figs. 2B, 8B) exhibits high frequency, high amplitude abundance fluctuations in sediment older than $690 \mathrm{ka}$ and abruptly drops off to trace abundances in the section younger than this age. Finally, G. truncatulinoides (left coiling; Figs. $2 \mathrm{D}, 8 \mathrm{C}$ ) is absent or rare in sediment between the ages of 930 and 670 $\mathrm{ka}$. In sediments older and younger than this interval, this species exhibits a series of abrupt increases (to $>10 \%$ ) and decreases in relatives abundances.

3. N. pachyderma (right coiling; Figs. 2B, 8B) exhibits two significant peaks in relative abundance $(>20 \%)$ during isotope Stage 20 (around $800 \mathrm{ka}$ ) and during the transition from isotope Stage 15 to 14 (around $540 \mathrm{ka}$ ); otherwise, its abundance generally remains below 
Figure 7. Time series of preservation indicators percent whole foraminifers and percent calcium carbonate between 23 and 43 mcd (500-1000 ka) at Site 927. Each time series is accompanied by the G. sacculifer $\delta^{18} \mathrm{O}$ chronology over the same time interval.
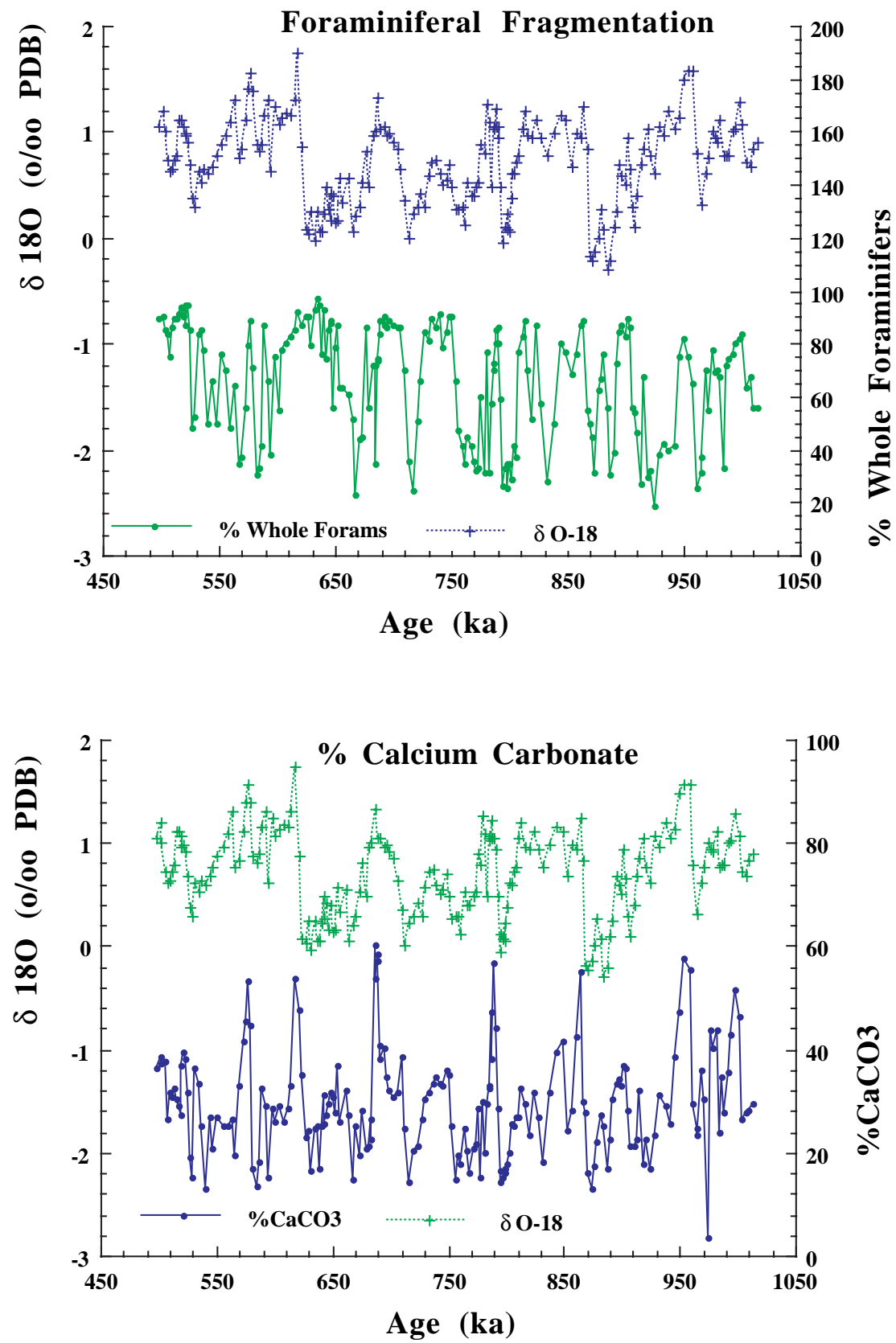

$5 \%$. These peaks correspond to peaks in the relative abundance of $N$. dutertrei (see N. dutertrei plot, Fig. 8A).

4. Globigerinoides tenellus is only abundant between 670 and 570 $\mathrm{ka}$, especially during the late part of isotope Stage 18 (Fig. 8C).

5. The less abundant species shown in Figures 2C and 2D (Globigerina falconensis, Globigerinella aequilateralis, G. truncatulinoides (right coiling), Globigerina bulloides, Globigerinoides conglobatus, and Globorotalia crassaformis) exhibit small amplitude, short-term fluctuations. Despite their generally low abundances, both G. falconensis and G. aequilateralis exhibit distinct intervals of generally higher relative abundances between 26 and $32 \mathrm{mcd}$ (isotope Stages 18-15) for G. aequilateralis and between 28 and 34 mcd (isotope Stages 19-17) and 37 and $40 \mathrm{mcd}$ (isotope Stages 25-22) for $G$. falconensis.

6. Downcore interrelationships among abundant species are not simple, and little systematic covariation exists among species. Abun- dance maxima and minima for any two species do not consistently correspond along the entire section, nor is there any consistent offset between the maxima and minima of species. Species abruptly increase and decrease in relative abundance at distinctly different intervals. Of the important species, only one species pair $(N$. dutertrei- $N$. pachyderma [right coiling]; $r=+0.65$ ) exhibits patterns of downcore variation that produce linear correlation coefficients above +0.3 . Decoupled species fluctuations downcore indicate that relative abundance patterns exhibit statistical independence. Faunas are of sufficient diversity so that matrix closure does not produce artificially high negative correlations between abundant species. In fact, only two species pairs ( $N$. dutertrei-G. glutinata, $r=-0.49$, and $G$. glutinata-P. obliquiloculata, $r=-0.40$ ) exhibit patterns of downcore variation with negative correlation coefficients better than -0.25 .

We have attempted to assess the degree that differential dissolution is influencing downcore variations in species relative abundances by 
comparing patterns of species variability to variations in the preservation indicators presented and discussed in the last section. Table 3 summarizes the degree of intercorrelation between changes in preservation using percent whole foraminifers and changes in the relative abundances of 13 species. There is a significant lack of correlation between percent whole foraminifers and the relative abundances of these species, which account for $90 \%$ of the average faunal composition. G. glutinata and G. tenellus, two dissolution susceptibility species (Cullen and Prell, 1984) and N. dutertrei and P. obliquiloculata, two dissolution resistant species (Cullen and Prell, 1984) are the only species that exhibit patterns of variation that are even somewhat correlated to changes in preservation. Thus, changes in foraminifer faunas from 23 to $43 \mathrm{mcd}$ at Site 927 do not seem to be appreciably controlled by differential dissolution and changes in preservation.

In summary, planktonic foraminifer faunas exhibit noteworthy variability between 23 and 43 mcd at Site 927 . Downcore patterns of variation for the important species are not highly correlated with each other, nor do they seem to be related in a simple manner to the glacial/ interglacial cycles defined by the chronology of stable isotope variations. In addition, downcore patterns of species variation do not seem to be significantly influenced by changes in carbonate preservation. Planktonic foraminifer faunas are not responding in a significant manner to modifications produced by differential dissolution. We conclude that the observed changes in planktonic foraminifer faunas at Site 927 are in response to changing environmental conditions in the surface waters above the site.

We chose to analyze Site 927 faunal data further by comparing downcore faunas to present-day faunas by means of the Modern Analog Technique (MAT). This technique has been used in the study of Quaternary palynology (e.g., Prentice, 1980; Overpeck et al., 1985) and was first applied to planktonic foraminifer data by Hutson (1979) and more recently by Prell (1985), Cullen and Droxler (1990), Howard and Prell (1992), Cullen et al. (1994), and Curry and Oppo (1997).

The MAT directly compares the faunal composition of a downcore sample with a set of modern surface sediment samples; in this study 1197 core-top samples from our new Global Data Base. Percentage data for 40 planktonic foraminifer taxonomic categories have been compiled in one laboratory using a slightly modified and very consistent, standardized taxonomy (Cullen and Martin, unpubl. data). Samples analyzed in a number of previous studies (e.g., Kipp [1976] and CLIMAP [1981] from the Atlantic; Hutson and Prell [1980] and Cullen and Prell [1984] from the Indian Ocean; Parker and Berger, 1971; Thompson [1976, 1981] and Coulbourn et al. [1980] from the Pacific), along with additional new samples, have been "repicked" (and in some cases resampled) by the taxonomic experts at Brown University using our standardized taxonomy.

We used the squared chord distance to calculate the dissimilarity between each sample at Site 927 and all samples in the new Global Data Base of modern core-top samples. Dissimilarity values can range from 0 (identical) to 2.0 (most dissimilar). We then identified the 10 most similar modern samples for each downcore sample and calculated the mean of the dissimilarity coefficients for each individual set of 10 modern analogs. Only 24 of the 200 Site 927 samples did not have 10 modern analogs with dissimilarity coefficients of less than 0.25 . The mean dissimilarity coefficient for the 10 best modern analogs for each downcore sample is plotted in Figure 10A and statistically summarized in Table 4 . Note that the highest mean dissimilarities occur between 25 and $26 \mathrm{mcd}$ and just below $35 \mathrm{mcd}$. These intervals correspond to the transitions between isotope Stages 15 and 14 and isotope Stages 21 and 20, respectively. Samples with the poorest modern analogs seem to contain abundant amounts of N. pachyderma (right coiling) and $N$. dutertrei. Both species exhibit systematic increases in abundance with increasing mean dissimilarity, with $r$ $=+0.57$ for $N$. pachyderma [right coiling] and $r=+0.63$ for $N$. dutertrei. Samples with the best set of modern analogs are rich in $G$. ruber, which exhibits systematic decreases in abundance with decreasing mean dissimilarity $(r=-0.65)$.

We used the MAT to compare downcore foraminifer faunas with modern Ceara Rise foraminifer faunas. We analyzed the faunal composition of 14 Ceara Rise surface sediment samples (locations shown in Fig. 1). We then calculated the mean dissimilarity of the 10 most similar Ceara Rise core-top samples for each downcore Site 927 sample. Downcore intervals with low mean dissimilarities have faunal compositions similar to faunas inhabiting the surface waters above the present-day Ceara Rise. Results are plotted vs. time along with the $\delta^{18} \mathrm{O}$ chronology in Figure 11. The low mean dissimilarities during much of isotope Stage $21(870-820 \mathrm{ka})$, and to a lesser extent during isotope Stages 19 and 17 (around 770 and $690 \mathrm{ka}$, respectively) suggest that surface water conditions during these intervals were much like the surface waters above the present-day Ceara Rise. The higher mean dissimilarities within the remainder of the section (compare with Fig. 10A) indicate that faunal compositions were significantly different during these times. These differences indicate that surface water conditions above the Ceara Rise differed from presentday conditions for significant intervals between 1000 and $500 \mathrm{ka}$.

\section{SST Variations Above Site 927}

The previous discussion suggests that downcore changes in planktonic foraminifer faunas are in response to changes in the environmental conditions of surface waters during the 1000 to $500 \mathrm{ka}$ time interval represented by Site 927 sediments found between 23 and $43 \mathrm{mcd}$. The surface water conditions above the subset of 10 best modern analogs for each Site 927 sample can be used to predict the surface water conditions above the site location at the time each sampled sediment interval was deposited.

For our new Global Data Base, we have compiled average February and August SSTs above each of the faunally analyzed core-top samples using the Global Ocean Surface Temperature Atlas (GOSTA; Bottomley et al., 1990), which is based on ship observations from 1951 to 1980 . These monthly average SSTs have been used to convert the SSTs into a data set of warm-season and cold-season SSTs. These data are used to estimate changes in SST above Site 927.

Cold and warm SSTs were calculated for each Site 927 downcore sample by averaging the set of cold and warm SSTs above the 10 best analogs identified from the new Global Data Base of modern seabed samples. Time series of the SST estimates, along with the stable isotope chronology, are presented in Figure 12 and are statistically summarized in Table 4. In general, sediment samples with the best analogs (lowest mean dissimilarity coefficients) produce SST estimates with the lowest standard deviations (compare downcore plots of standard deviations with plot of mean dissimilarity; Fig. 10). The standard deviations for both warm and cold SST estimates exhibit a systematic increase with increasing mean dissimilarity $(r=+0.36$ and +0.41 for warm and cold standard deviations, respectively; Fig. 10).

Warm SST estimates fluctuate around a mean of $27.6^{\circ} \mathrm{C}$, just slightly below present-day observed warm SSTs $\left(28.0^{\circ} \mathrm{C}\right)$. Temperatures are more stable before $800 \mathrm{ka}$ (around isotope Stage 20) where the amplitude of temperature variation is generally less than $1^{\circ} \mathrm{C}$. After $800 \mathrm{ka}$ there is a distinct increase in the amplitude of warm SST variability to near $20^{\circ} \mathrm{C}$. Highest warm SST estimates occur during interglacial Stages 19, 17, and 15. Cold SST estimates exhibit greater amplitude variability (between $2^{\circ}$ and $4^{\circ} \mathrm{C}$ ) than warm SST estimates with a mean of $25.1^{\circ} \mathrm{C}$, which is a full $2^{\circ} \mathrm{C}$ colder than modern cold SSTs above the Ceara Rise. In fact, only for six very brief time intervals do estimates of cold SST approach $27^{\circ} \mathrm{C}$. Thus, cold SSTs above the Ceara Rise remain below modern levels for the bulk of time between 500 and $1000 \mathrm{ka}$. Not surprisingly, two of the three coldest intervals correspond to peaks in the relative abundance of $N$. pachyder$m a$ (right coiling) during glacial Stages 20 and 14. Highest cold SST 

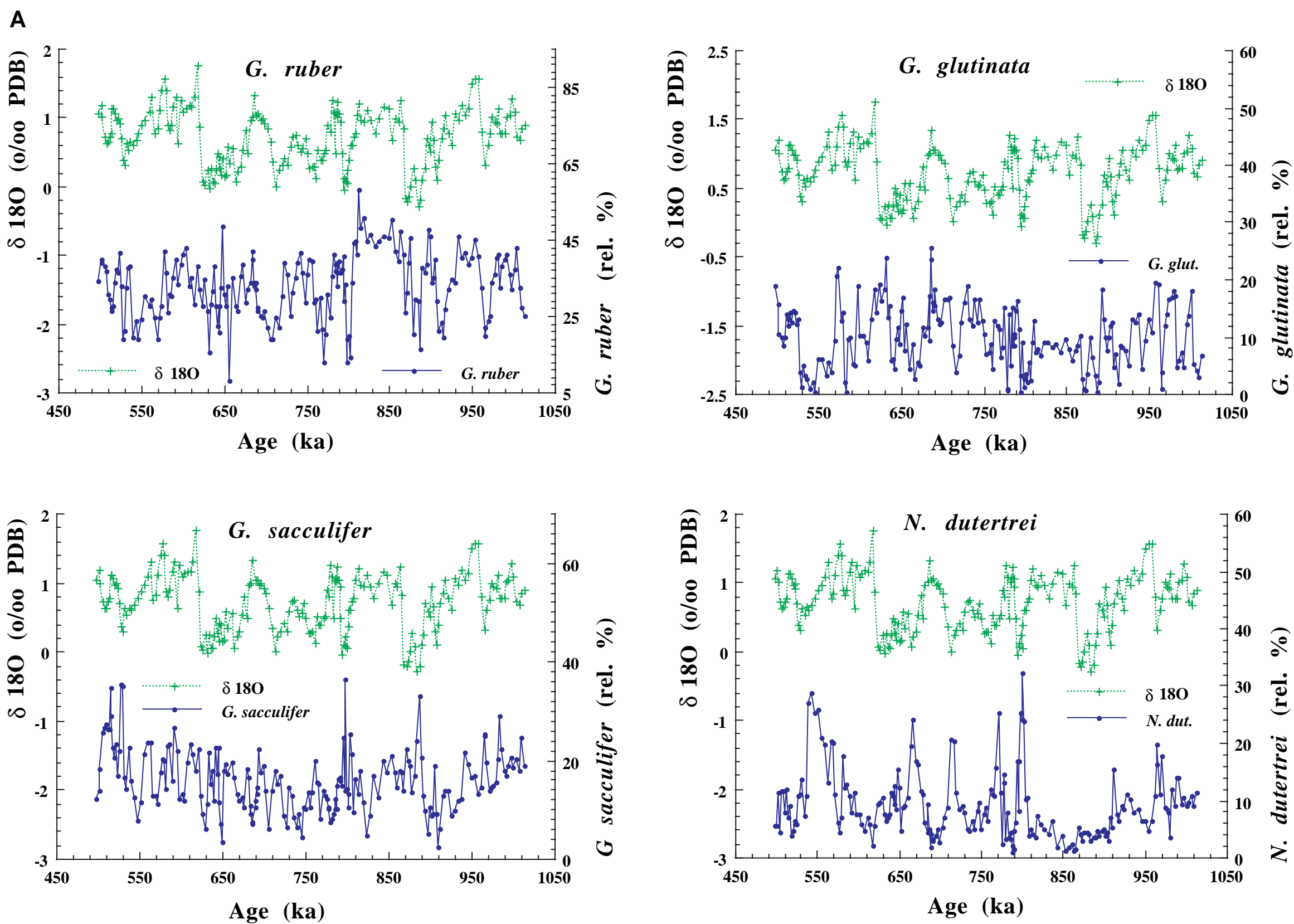

Figure 8. Time series of the 12 most abundant species of planktonic foraminifers found between 23 and 43 mcd in Site 927 . Each time series is accompanied with the G. sacculifer $\delta^{18} \mathrm{O}$ chronology over the same time interval. A. Time series for G. ruber, G. sacculifer, G. glutinata and N. dutertrei. B. Time series for G. menardii complex, P. obliquiloculata, G. rubescens, and N. pachyderma (right coiling). C. Time series for G. tenellus and G. truncatulinoides, left coiling. 

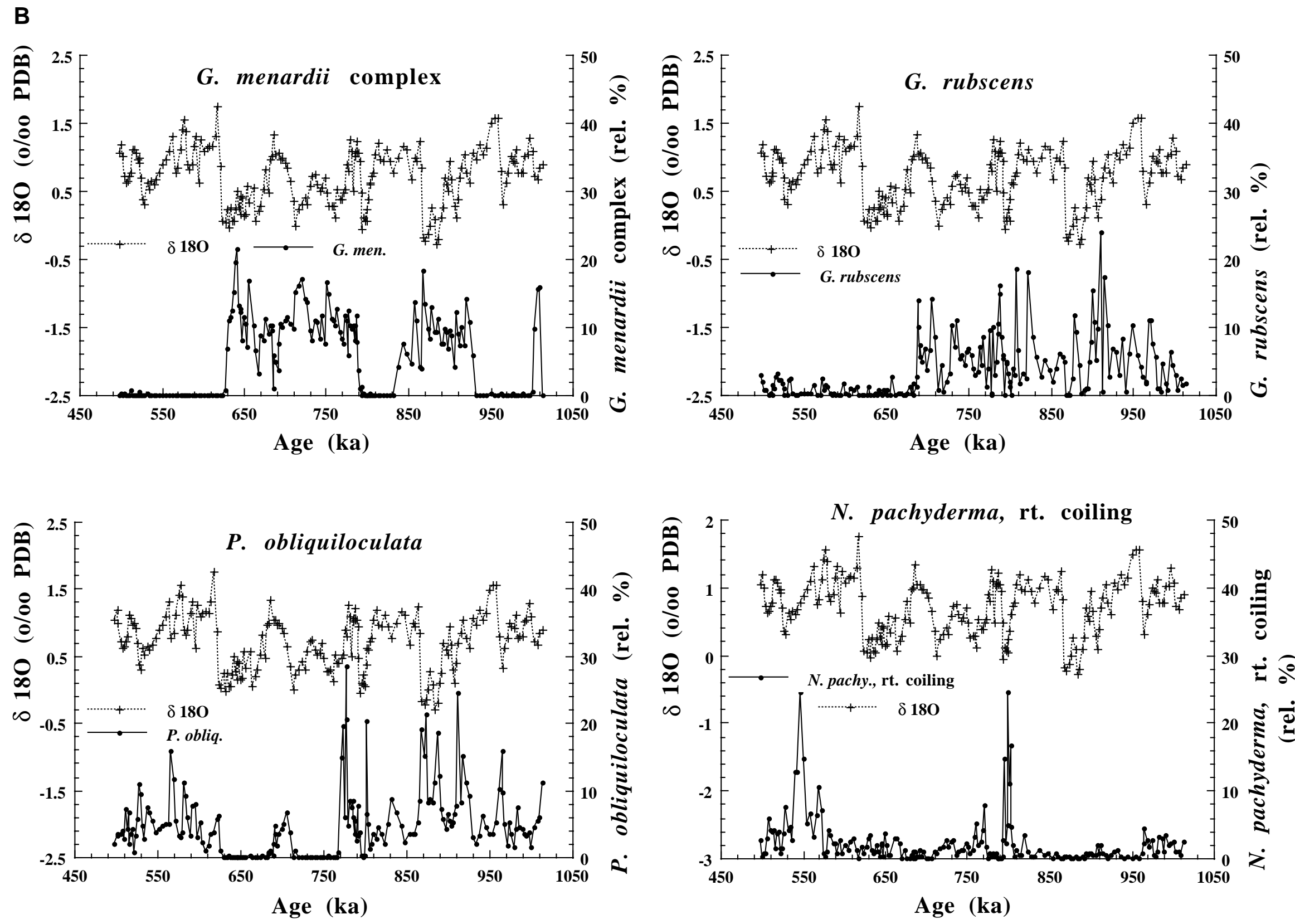

Figure 8 (continued) 
Figure 8 (continued).
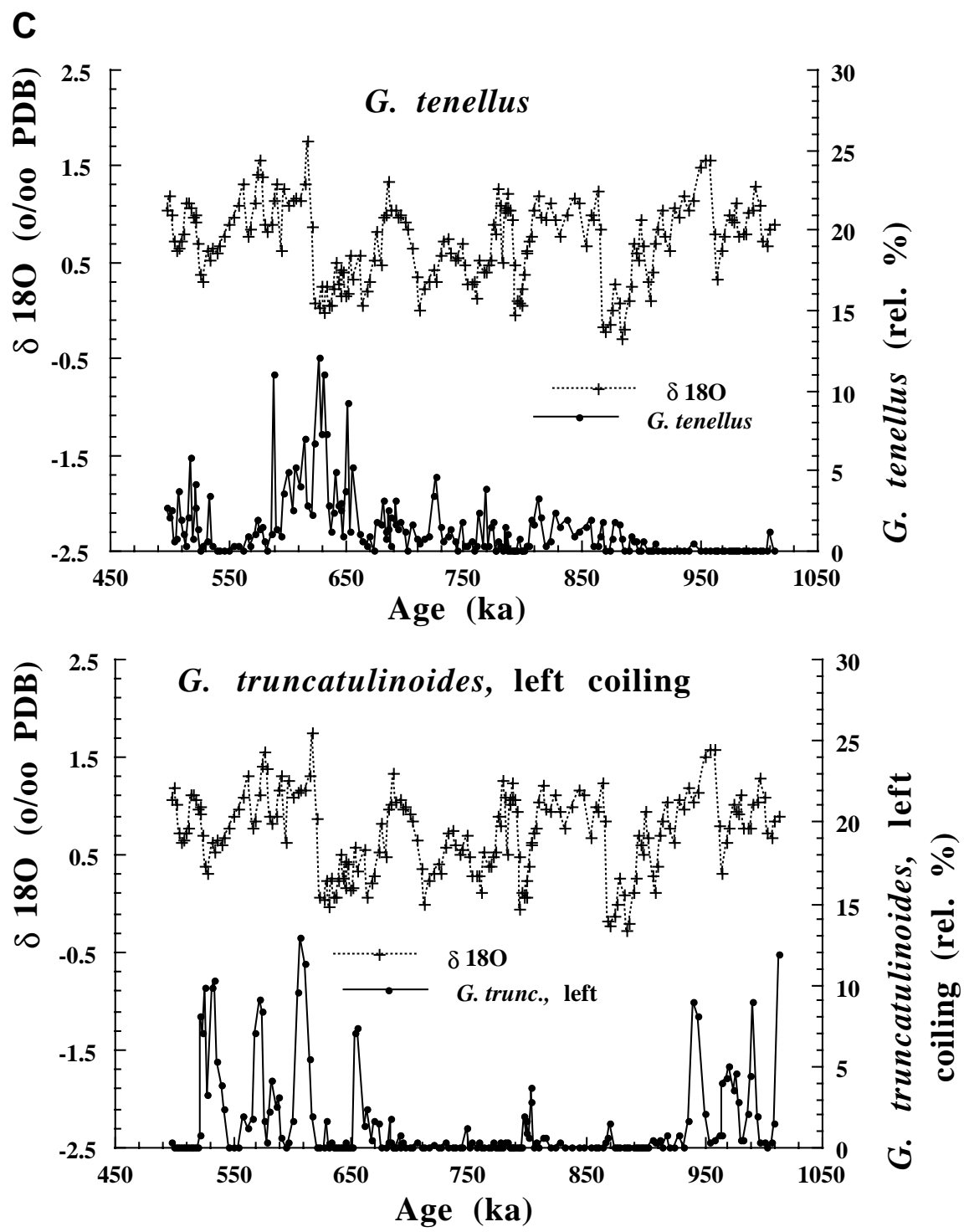

Figure 9. Time series of variations G. sacculifer relative abundance plotted with time series of variations in its $\delta^{13} \mathrm{C}$ content. Note similar patterns of low frequency variability.

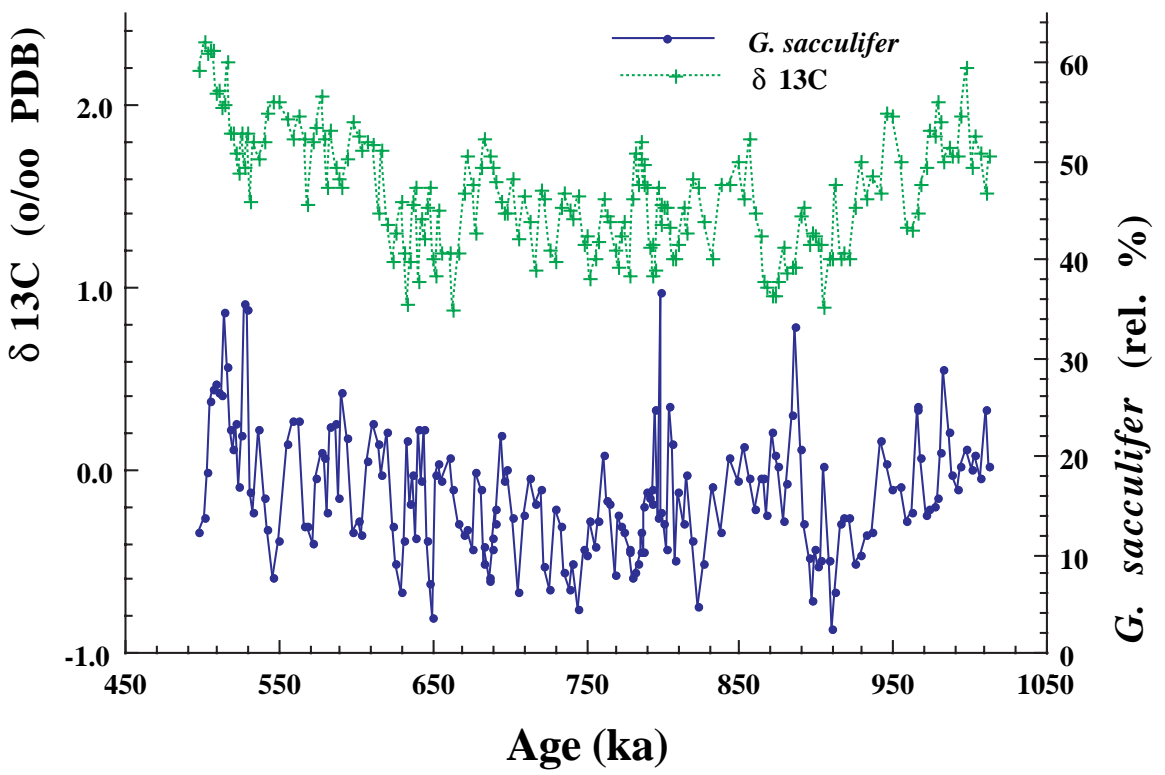


Table 3. Linear correlations between percent whole foraminifers, MAT estimates of warm and cold SST, and important downcore foraminifer species between 23 and 43 mcd in Site 927.

\begin{tabular}{lccc}
\hline \multicolumn{1}{c}{ Species and other variables } & $\begin{array}{c}\text { \% Whole } \\
\text { foraminifers }\end{array}$ & $\begin{array}{c}\text { Warm SST } \\
\text { estimate }\end{array}$ & $\begin{array}{c}\text { Cold SST } \\
\text { estimate }\end{array}$ \\
\hline G. ruber & +0.27 & +0.04 & +0.18 \\
G. sacculifer & -0.01 & -0.09 & +0.10 \\
G. glutinata & +0.56 & +0.33 & +0.21 \\
G. dutertrei & -0.50 & -0.08 & -0.34 \\
G. menardii & +0.03 & -0.30 & 0.00 \\
P. obliquiloculata & -0.42 & +0.21 & +0.14 \\
G. rubescens & +0.16 & +0.03 & +0.21 \\
G. pachyderma, right coiling & -0.25 & -0.27 & -0.45 \\
G. falconensis & +0.08 & -0.07 & -0.31 \\
G. truncatulinoides, right coiling & +0.03 & -0.21 & -0.23 \\
G. truncatulinoides, left coiling & 0.00 & 0.00 & -0.22 \\
G. tenellus & +0.40 & -0.03 & -0.17 \\
Cold SST estimate & +0.13 & +0.60 & \\
Warm SST estimate & +0.03 & & +0.60 \\
Mean dissimilarity, 10 best modern analogs & -0.28 & -0.09 & -0.40 \\
\% CaCO & +0.60 & +0.25 & +0.31 \\
\% RSP & -0.59 & -0.23 & -0.37 \\
Coarse fraction $(\%>63 \mu \mathrm{m})$ & +0.63 & +0.29 & +0.40 \\
\hline
\end{tabular}

estimates occur during interglacial Stage 17 and just before and after glacial Stage 26.

A comparison of downcore estimated SST patterns with downcore relative abundance variations of important foraminifer species reveals no obvious correspondence among patterns (except for $N$. pachyderma [right coiling], see above). None of the 12 most important species patterns are highly correlated to estimated SST patterns, particularly for warm SSTs. Only two species, G. glutinata and $G$. menardii, exhibit even slight linear correlation to estimated warm SSTs $(r=+0.33$ and -0.30 for these two species, respectively). $N$. pachyderma (right coiling), $N$. dutertrei, and G. falconensis exhibit slight negative correlation to estimated cold SSTs (Table 3). These
Table 4. Statistical summary of downcore MAT dissimilarity measures and MAT estimates of SST between 23 and 43 mcd in Site 927.

\begin{tabular}{lcccc}
\hline \multicolumn{1}{c}{ MAT variable } & Mean & SD & Maximum & Minimum \\
\hline Cold SST estimate $\left({ }^{\circ} \mathrm{C}\right)$ & 25.1 & 0.9 & 27.4 & 21.2 \\
SD, cold SST estimates $\left({ }^{\circ} \mathrm{C}\right)$ & 1.6 & 0.5 & 4.1 & 0.4 \\
Warm SST estimate $\left({ }^{\circ} \mathrm{C}\right)$ & 27.6 & 0.5 & 28.9 & 25.3 \\
SD, warm SST estimates $\left({ }^{\circ} \mathrm{C}\right)$ & 0.9 & 0.3 & 2.5 & 0.2 \\
Mean dissimilarity, 10 best modern analogs & 0.17 & 0.06 & 0.32 & 0.07 \\
SD diss., 10 best modern analogs & 0.02 & 0.01 & 0.04 & 0.00 \\
Mean dissimilarity, Ceara Rise analogs & 0.28 & 0.11 & 0.08 & 0.77 \\
SD, Ceara Rise analogs & 0.02 & 0.01 & 0.01 & 0.05 \\
\hline
\end{tabular}

Note: See text for complete explanation of each MAT variable; SD = standard deviation.

observations suggest that downcore faunal changes are likely in response to ecologically important near surface water environmental conditions other than SST. A similar conclusion was reached while studying a 600 k.y. record from the tropical Indian Ocean (Cullen and Droxler, 1990).

\section{DISCUSSION}

In previous sections, we have attempted to demonstrate that, even though the various indicators of carbonate preservation examined do exhibit changes downcore and, to some extent, must be recording changes in preservation and in the relative amounts of carbonate dissolution, differential dissolution does not seem to significantly control changing relative abundance patterns for the important planktonic foraminifer species identified in Site 927 sediments. Our analysis suggests that planktonic foraminifer variability is predominately controlled by changing conditions in the surface waters above the Ceara Rise. In addition, we have estimated past changes in SST using the Modern Analog approach. Comparison of downcore changes in esti-

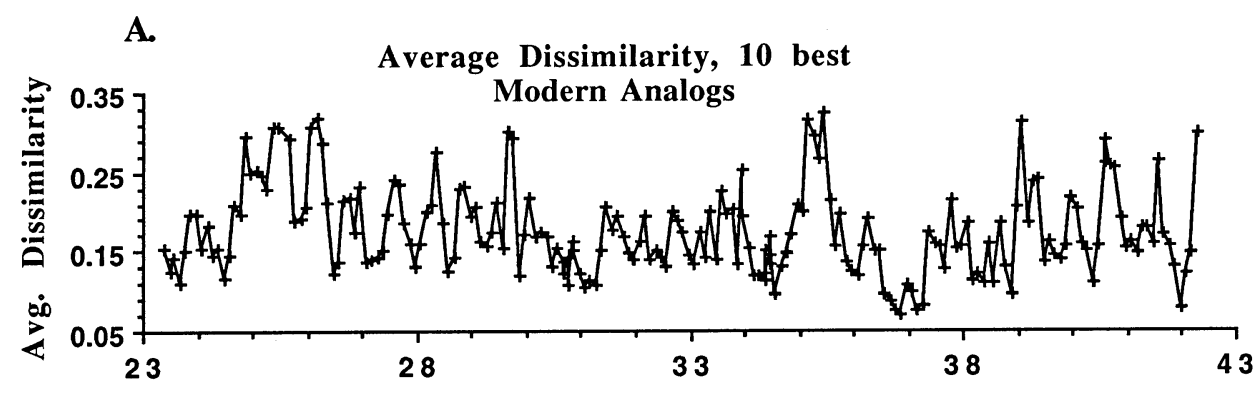

B.
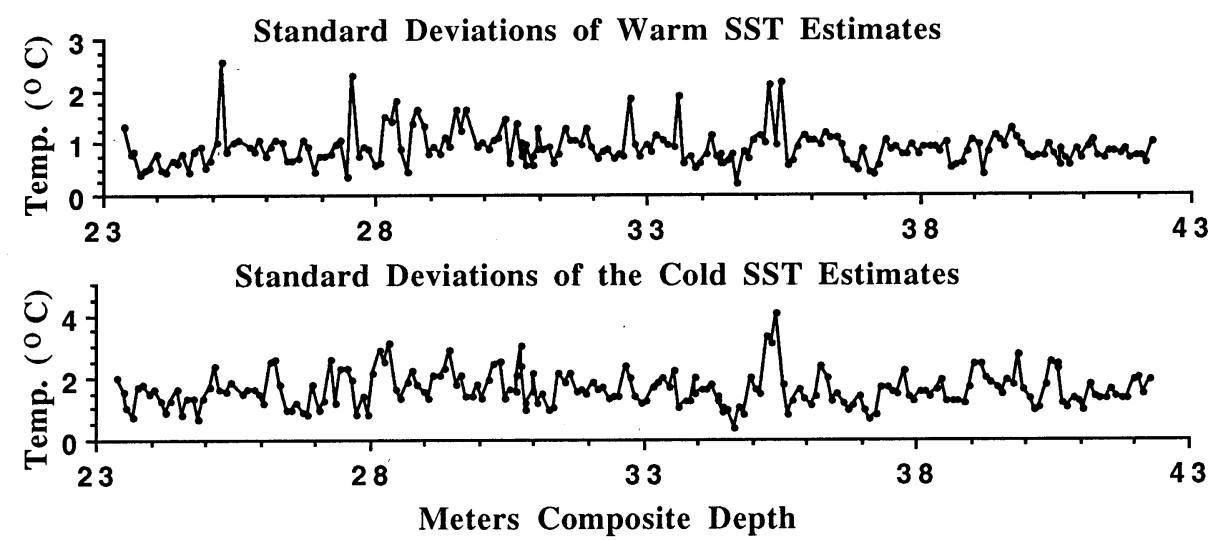

Figure 10. A. Downcore variations in the means of the dissimilarity coefficients of the 10 modern surface sediment analogs most similar to each downcore sample between 23 and 43 mcd in Site 927. B. Downcore variations in the standard deviations of the downcore cold and warm SST estimates using SSTs above each of the 10 best modern analogs. 


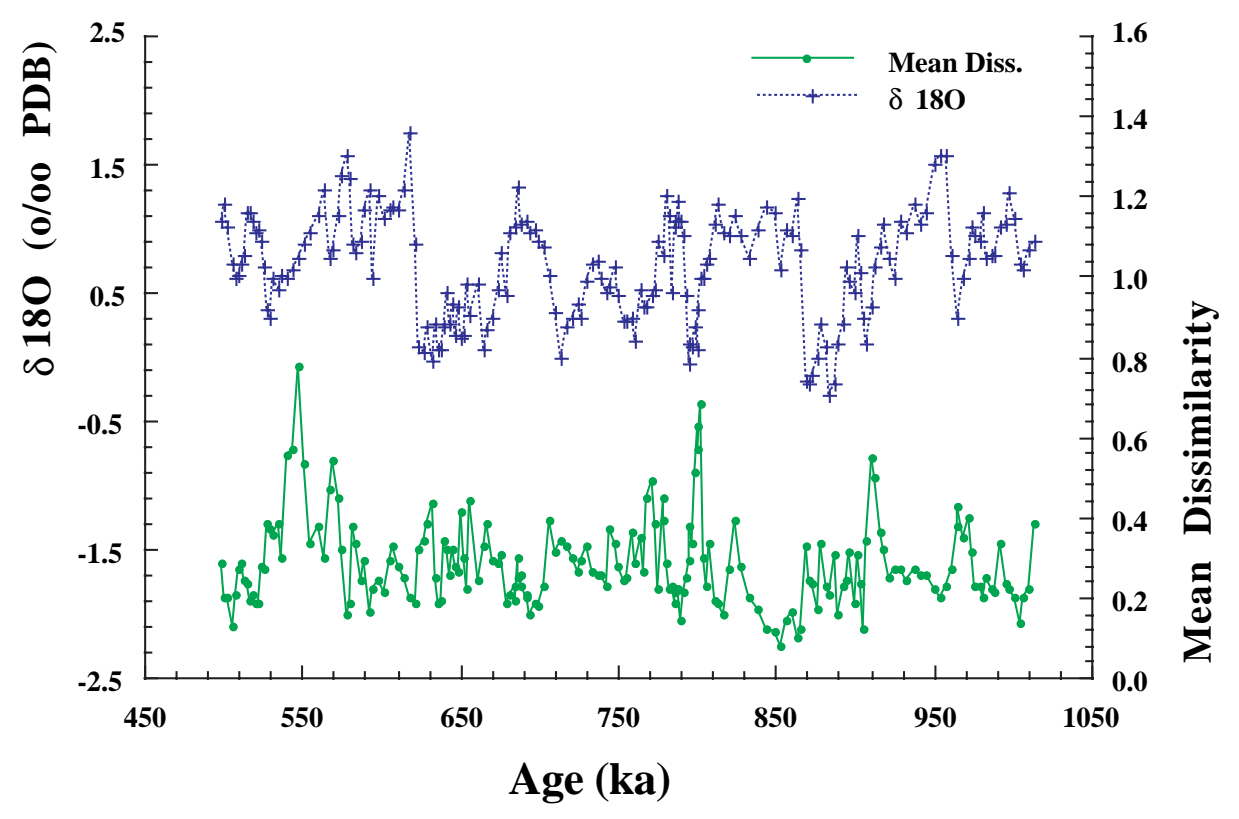

Figure 11. Time series of variations in the means of the dissimilarity coefficients of the 10 modern Ceara Rise surface sediment analogs most similar to each Site 927 sample between 500 and $1000 \mathrm{ka}$. Time series of $\delta^{18} \mathrm{O}$ variations in G. sacculifer is included for comparison.

mated warm and cold SSTs with the well-documented changes in the abundances of major foraminifer species suggests that changes in surface water conditions other than SST are controlling patterns of foraminifer variability in the western tropical Atlantic. This conclusion is supported by the observed lack of correlation between downcore estimated SSTs and patterns of species variability and by the additional fact that variations in estimated downcore SSTs are not large over the same Site 927 depth interval that exhibits a significant amount of planktonic foraminifer species variability. The planktonic foraminifer faunal data from 23 to 43 mcd at Site 927 exhibits significant changes in response to changing environmental conditions in the surface waters, which are not likely reflected by changes in SSTs above the Ceara Rise.

In their studies of planktonic foraminifer faunas from surface sediments in the tropical Atlantic Ocean, Ravelo et al. (1990) and Ravelo and Fairbanks (1992) have related spatial variations in faunas to changes in the hydrographic conditions of the overlying surface water layer. They found that tropical Atlantic faunal factor assemblages (calculated using Q-mode factor analysis) are not as highly correlated to cold and warm SSTs as they are to other aspects of the ocean surface layer like depth of the mixed layer, thermocline depth and seasonality, and surface seasonality. For example, one factor assemblage, dominated by G. ruber, G. glutinata, and to a lesser extent $G$. sacculifer (species known to calcify in the mixed layer; Ravelo and Fairbanks, 1992), correlates well to mixed layer depth, dominating regions in the tropical Atlantic where the mixed layer is deep all year (western regions including Ceara Rise area). Another factor assemblage dominated by G. menardii, N. dutertrei, P. obliquiloculata, and $G$. tumida, which are found in greatest abundances within narrow depth ranges in the thermocline where the chlorophyll maximum is located (and thus, primary production is at a maximum; Fairbanks and Wiebe, 1980; Fairbanks et al., 1980, 1982; Ortner et al., 1980), seems to be most abundant in regions where surface temperature seasonality is low and the thermocline moves into the photic zone (eastern tropical Atlantic between $0^{\circ}$ and $15^{\circ} \mathrm{N}$; Ravelo et al., 1990).

The results presented in Ravelo et al. (1990) suggest that downcore variations in the G. ruber, G. sacculifer, and G. glutinata species sum and the N. dutertrei, P. obliquiloculata, $G$, menardii, and $G$. tumida species sum in Site 927 may reveal information on changing hydrographic conditions above the Ceara Rise. The increase in the sum of the "thermocline" species relative to the "mixed layer" species may be a simple way to indicate times when the mixed layer is shallow and the thermocline remains in the photic zone for significant intervals during the annual cycle. The species sum plots are presented in Figure 13. The two species sum plots exhibit strong negative correlation $(r=-0.81)$. Both plots exhibit cyclic variation on glacial/interglacial time scales with the sum of the "mixed layer" species dominating interglacial intervals and the observed maxima in the sum of the "thermocline" species occurring during glacial intervals (Fig. 13). This suggests that, from 1000 to $500 \mathrm{ka}$, the surface layer hydrography above the Ceara Rise during glacial times may have been more similar to present-day conditions observed farther to the east in the tropical Atlantic. Such changes could have important implications regarding surface water circulation patterns in the tropical Atlantic.

The interpretations we have presented above are considered preliminary in nature and will be further investigated in future work upon the completion of the Site 927 faunal record for the past 1 m.y. Two additional observations substantiate the preliminary nature of our above interpretations.

1. The calculated faunal assemblages from tropical Atlantic surface sediments by Ravelo et al. (1990) indicate that the patterns of distribution among species with high loadings on the same faunal factor are correlated and positively covary. Thus, Site 927 downcore relative abundance variations among $G$. ruber, G. glutinata, and G. sacculifer, as well as among species in the grouping of N. dutertrei, P. obliquiloculata, G. menardii, and G. tumida, should positively covary if species associations in the tropical Atlantic have not changed through time. As indicated by comparing downcore species variations in Figures 2 or 8 , the correlation coefficients of downcore relative abundances among species within the same groupings are small. Thus, species associations may be changing with time. Ravelo et al. (1990) observed differences in species associa- 

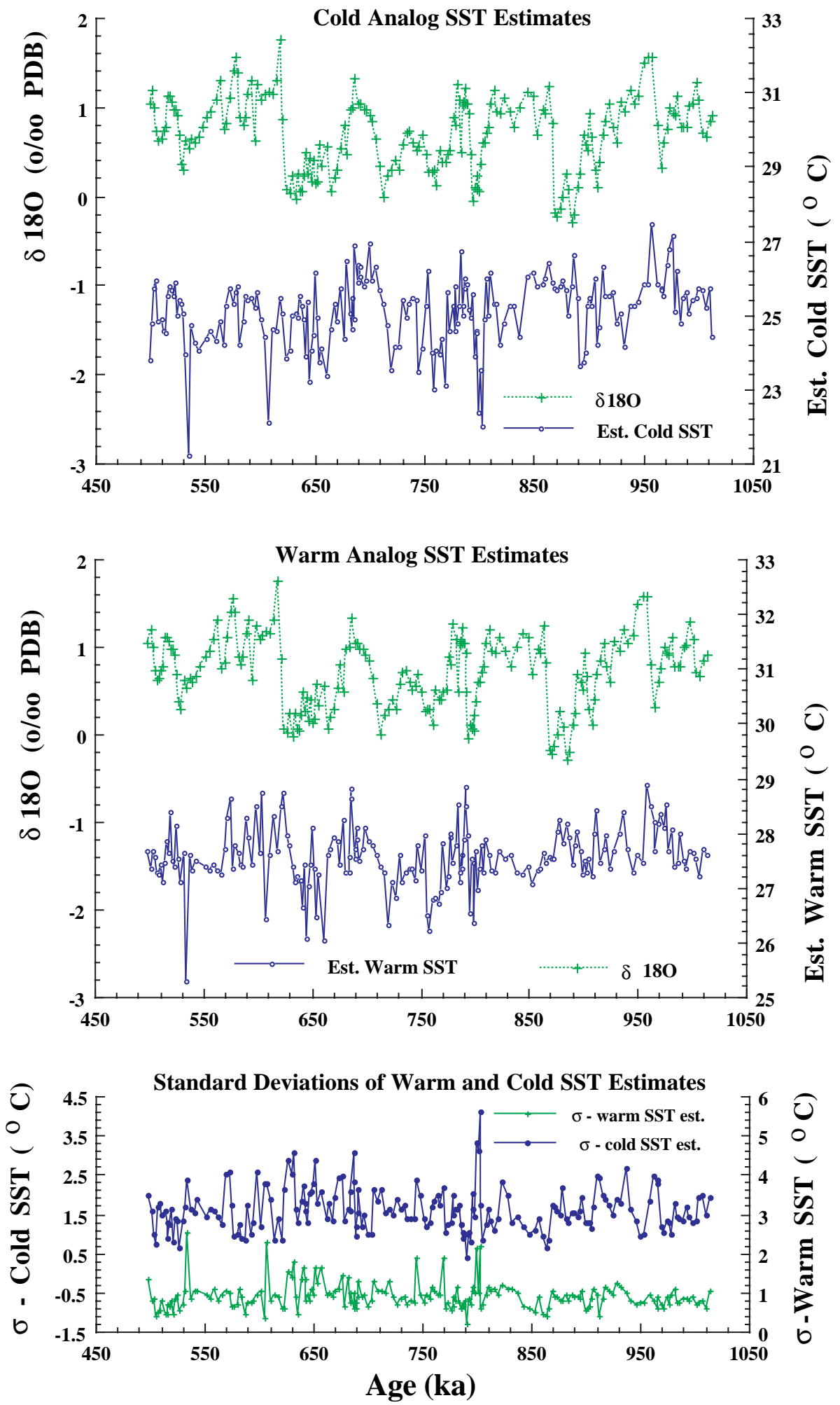

Figure 12. Time series of variations in warm and cold SSTs estimated by averaging the SSTs above the 10 best modern analogs for each Site 927 sample between 500 and $1000 \mathrm{ka}$. G. sacculifer $\delta^{18} \mathrm{O}$ time series is included with both SST plots for comparison. Below the SST plots, time series of the standard deviations for the cold and warm estimated SSTs are included. 


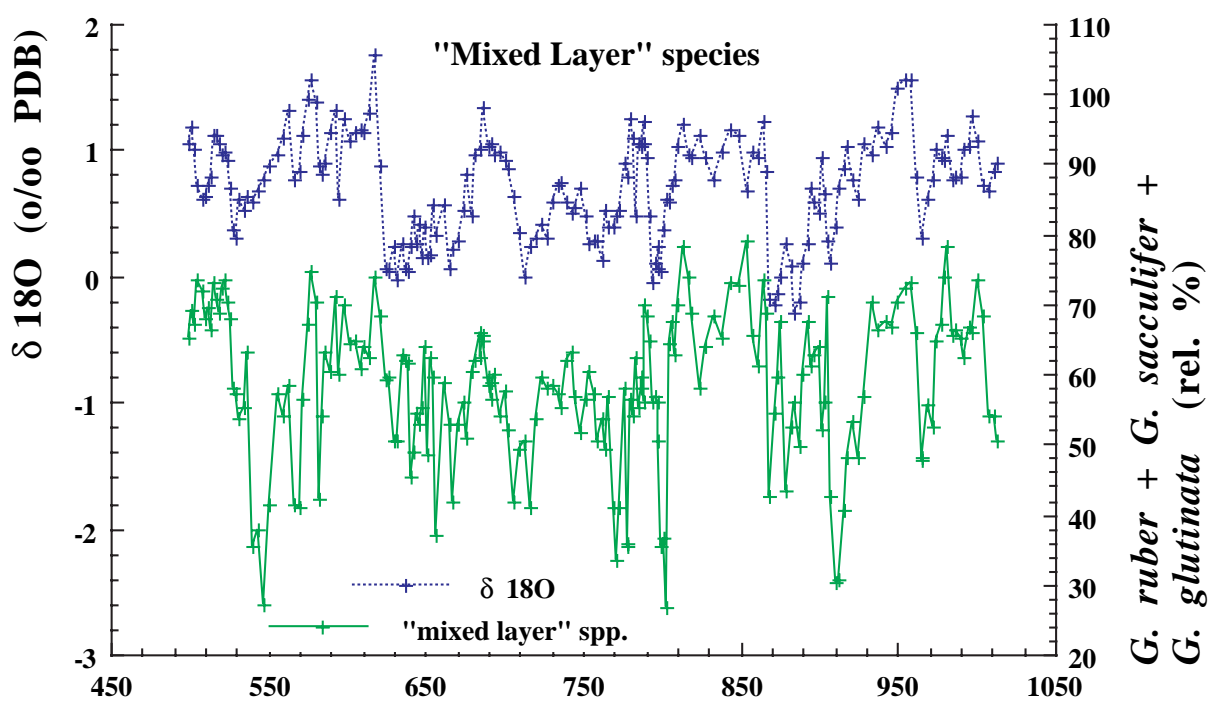

Figure 13. Time series of the relative abundance sums of "mixed layer" species and the relative abundance sums of "thermocline" species during the 500-1000 ka time interval at Site 927. G. sacculifer $\delta^{18} \mathrm{O}$ time series is included in both plots for comparison.

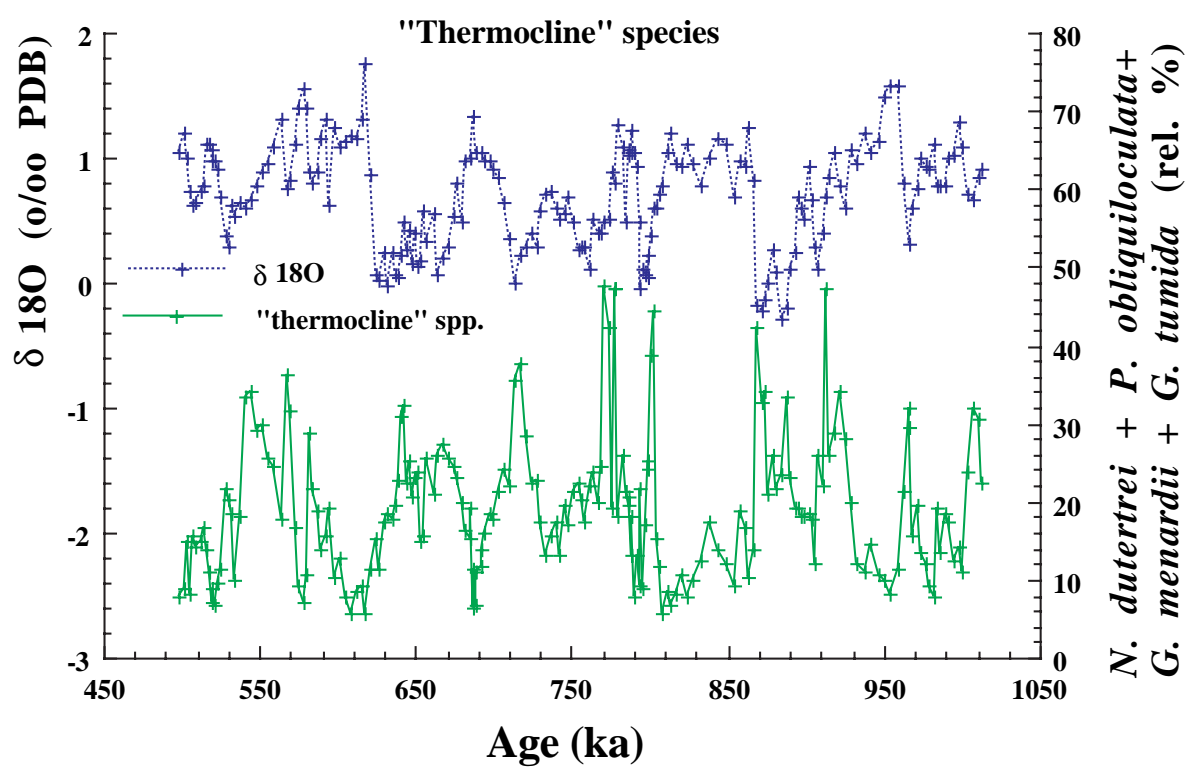

tions between modern and Last Glacial Maximum sediments from the tropical Atlantic.

2. The two species sums we plotted downcore (Fig. 12) have much higher correlations to changes in preservation as expressed by percent whole foraminifers than any of the individual species $(r=+0.45$ between the "mixed layer" species sum and percent whole foraminifers, and $r=-0.57$ between the "thermocline" species sum and percent whole foraminifers). Therefore, some of the observed downcore changes may be artifacts of preservation and not totally related to hydrographic changes in the surface water layer above the Ceara Rise.

In summary, much of the observed species variability between 1000 and $500 \mathrm{ka}$ in Site 927 may be related to changes in the mixed layer depth and the amount of time the thermocline is in the photic zone during the annual cycle. Our preliminary interpretations suggest that during glacial intervals, hydrographic conditions were more similar to present-day conditions observed toward the eastern parts of the tropical Atlantic, whereas during interglacial intervals, the mixed layer remained thick and the thermocline was well below the photic zone. However, these interpretations cannot fully explain the previously discussed numerous large-scale and abrupt downcore changes in relative abundances observed by many species (see Figs. 2B, 2C, $8 \mathrm{~B}, 8 \mathrm{C})$

\section{SUMMARY AND CONCLUSIONS}

The work presented here represents our initial results at documenting and interpreting patterns of variability in planktonic foraminifer species relative abundances at Site 927, a shallow water $(3315 \mathrm{~m})$ Leg 154 site from the Ceara Rise in the western tropical Atlantic within the middle Pleistocene (1000-500 ka). Species patterns were examined and interpreted within the context of changing states of carbonate preservation in order to evaluate the extent that changing foraminifer faunas are reflecting variations in surface water conditions within an area that is now a warm pool of nutrient-depleted surface water above a deep mixed layer. Changes in sea-surface temper- 
ature (cold and warm season) were estimated from foraminifer faunas using the Modern Analog Technique and a new Global Data Base of faunally analyzed surface sediment samples. Changing faunas were further interpreted on a preliminary basis in terms of changing hydrographic conditions in the surface water layer above the Ceara Rise. Our initial results are summarized below.

1. Site 927 sediments exhibit systematic cyclic changes in preservation and carbonate content. Downcore variations in preservation indicators are not as highly correlated as they are in tropical Atlantic surface and Ceara Rise modern sediments. Downcore changes in preservation are best reflected by changes in percent whole foraminifers. Downcore records of both percent carbonate and percent resistant species (RSP) exhibit variability that is not related in a simple way to changes in preservation.

2. Many downcore percent whole foraminifer values in Site 927 fall below values typical of well-preserved modern sediments found above the foraminiferal lysocline in the present-day tropical Atlantic Ocean and identify intervals that have likely been affected to some extent by differential dissolution.

3. The same six species that dominate tropical Atlantic surface modern sediments dominate foraminifer faunas found between 23 and 43 mcd at Site 927 (Table 1).

4. The four most abundant species (G. ruber, G. sacculifer, G. glutinata, and $N$. dutertrei) show systematic high frequency fluctuations with amplitudes predominately in the $10 \%-20 \%$ range. A number of other important species (G. menardii, P. obliquiloculata, $G$. rubescens, G. tumida, G. truncatulinoides [left coiling], and G. tenellus) exhibit abrupt, relatively high amplitude increases and decreases in relative abundances superimposed upon higher frequency and lower amplitude variability. For $G$. sacculifer, higher frequency changes seem to be superimposed upon a longer term trend that is positively correlated with changes in its $\delta^{13} \mathrm{C}$ content. Finally, $N$. pachyderma (right coiling) exhibits two abrupt and significant increases in relative abundance during isotope Stage 20 and during the transition from isotope Stage 15 to 14 .

5. Downcore interrelationships among abundant species are not simple. There is little apparent linear covariation among species.

6. There is a significant lack of correlation between changes in preservation (as expressed by changes in percent whole foraminifers) and changes in the relative abundances of the 13 most important downcore species. Thus, changes in foraminifer faunas in the studied interval at Site 927 do not seem to be appreciably modified by differential dissolution.

7. The Modern Analog technique was used to directly compare downcore foraminifer faunas with present-day faunas. Only 24 of the downcore samples did not have 10 modern analogs with dissimilarities of less than 0.25 . Downcore samples with the poorest modern analogs had high abundances of $N$. pachyderma (right coiling) and $N$. dutertrei. Samples with the best set of modern analogs are rich in $G$. ruber. Downcore samples were directly compared with present-day Ceara Rise foraminifer faunas using the MAT. High mean dissimilarities downcore indicate that surface water conditions above the Ceara Rise differed from present-day conditions for significant intervals between 1000 and $500 \mathrm{ka}$.

8. Reasonably reliable estimates of cold and warm SST were calculated using the Modern Analog approach. Warm SST estimates vary little, except for a few isolated excursions; the amplitude of warm SST variations is somewhat greater after $800 \mathrm{ka}$. Cold SST estimates show more variability and, for the most part, remain below present-day values $\left(27.0^{\circ} \mathrm{C}\right)$ for most of the time interval studied.

9. Observed downcore faunal variability is considerably greater than would be expected from examination of the SST estimates. There is a distinct lack of correlation between species abundances and SST estimates suggesting that species are responding to surface water conditions other than SST. Present-day faunal relationships in the tropical Atlantic have been related to changes in the hydrography of the surface water layer, namely the depth of the mixed layer, the extent to which the thermocline is in the photic zone during the annual cycle, and SST seasonality (Ravelo et al., 1990).

10. At Site 927, species that are most abundant in present-day sediments below areas where the mixed layer is thick (G. ruber, G. glutinata, and G. sacculifer; Ravelo et al., 1990) dominate interglacial intervals. "Thermocline" species (N. dutertrei, P. obliquiloculata, G. menardii, and G. tumida; Ravelo et al., 1990) that are more abundant in sediments below areas where the thermocline spends considerable time in the photic zone during the annual cycle and SSTs don't vary much are much more abundant during glacial intervals between 1000 and $500 \mathrm{ka}$ in Site 927 sediments. Therefore, during these glacial intervals the surface water layer above the Ceara Rise is more similar to conditions toward the eastern part of the present-day tropical Atlantic (shallower mixed layer, for example) and suggests that tropical Atlantic patterns of surface circulation were different.

\section{ACKNOWLEDGMENTS}

This research was supported by USSAC-JOI grants to J.L. Cullen and W.B. Curry. We thank the personnel of the ODP Core Repository in Bremen, Germany for assistance during core sampling. We especially thank Susan Prew and Jennifer Cook for their expert species identification work. We thank D.R. Ostermann for producing most of the carbonate and stable isotope data. In addition, we thank $\mathrm{K}$. Schaeffer-Ganley, J. Paiva, K. Kecy, J. DaSilva, and K. Maglio for their capable technical assistance during sample processing and analysis. Finally, we thank Joey for assuring the success of Leg 154.

\section{REFERENCES}

Berger, W.H., 1970. Planktonic foraminifera: selective solution and the lysocline. Mar. Geol., 8:111-138.

1975. Deep-sea carbonates: dissolution profiles from foraminiferal preservation. In Sliter, W.V., Bé, A.W.H., and Berger, W.H. (Eds.), Dissolution of Deep-Sea Carbonate. Spec. Publ., Cushman Found. Foraminiferal Res., 13:82-86.

Berger, W.H., Bonneau, M.-C., and Parker, F.L., 1982. Foraminifera on the deep-sea floor: lysocline and dissolution rate. Oceanol. Acta, 5:249-258.

Bottomley, M., Folland, C.K., Hsiung, J., Newell, R.E., and Parker, D.E., 1990. Global Ocean Surface Temperature Atlas. Meteorological Office and Mass. Inst. of Technol.

Chen, M.-T., and Farrell, J., 1991. Planktonic foraminifer faunal variations in the northeastern Indian Ocean: a high-resolution record of the past 800,000 years from Site 758. In Weissel, J., Peirce, J., Taylor, E., Alt, J., et al., Proc. ODP, Sci. Results, 121: College Station, TX (Ocean Drilling Program), 125-140.

CLIMAP Project Members, 1976. The surface of the ice-age Earth. Science, 191:1131-1137.

, 1981. Seasonal reconstructions of the Earth's surface at the last glacial maximum. Geol. Soc. Am., Map and Chart Ser., MC36.

Coulbourn, W.T., Parker, G.L., and Berger, W.H., 1980. Faunal and solution patterns of planktonic foraminifera in surface sediments of the North Pacific. Mar. Micropaleontol., 5:329-399.

Craig, H., 1957. Isotopic standards for carbon and oxygen and correction factors for mass-spectrometric analysis of carbon dioxide. Geochim. Cosmochim. Acta, 12:133-149.

Cullen, J.L., 1981. Microfossil evidence for changing salinity patterns in the Bay of Bengal over the last 20,000 years. Palaeogeogr., Palaeoclimatol., Palaeoecol., 35:315-356.

, 1985. Models of planktonic foraminiferal biogeography in northern Indian Ocean surface sediments: the role of environment and preservation. Geol. Soc. Am., Abstr. Programs, 17:557.

Cullen, J.L., Curry, W.B., and Prell, W.L., 1994. Testing the accuracy of foraminiferal SSTs. Eos, 75:56.

Cullen, J.L., and Droxler, A.W., 1990. Late Quaternary variations in planktonic foraminifers faunas and pteropod preservation in the equatorial Indian Ocean. In Duncan, R.A., Backman, J., Peterson, L.C., et al., Proc. ODP, Sci. Results, 115: College Station, TX (Ocean Drilling Program), 579-588. 
Cullen, J.L., and Prell, W.L., 1984. Planktonic foraminifera of the northern Indian Ocean: distribution and preservation in surface sediments. Mar. Micropaleontol., 9:1-52.

Curry, W.B., and Lohmann, G.P., 1985. Carbon deposition rates and deep water residence time in the equatorial Atlantic Ocean throughout the last 160,000 years. In Sundquist, E.T., and Broecker, W.S. (Eds.), The Carbon Cycle and Atmospheric $\mathrm{CO}_{2}$ : Natural Variations Archean to Present. Geophys. Monogr., Am. Geophys. Union, 32:285-301.

Curry, W.B., and Lohmann, G.P., 1986. Late Quaternary carbonate sedimentation at the Sierra Leone Rise (eastern equatorial Atlantic Ocean). Mar. Geol., 70:223-250.

Curry, W.B., and Oppo, D.W., 1997. Synchronous, high-frequency oscillations in tropical sea surface temperatures and NADW production during the last glacial cycle. Paleoceanography, 12:1-4.

Curry, W.B., Shackleton, N.J., Richter, C., et al., 1995. Proc. ODP, Init. Repts., 154: College Station, TX (Ocean Drilling Program).

Ericson, D.B., and Wollin, G., 1956. Correlation of six cores from the equatorial Atlantic and Caribbean. Deep-Sea Res., 3:104-125.

, 1968. Pleistocene climates and chronology in deep-sea sediments. Science, 162:1227-1234.

Fairbanks, R.G., Sverdlove, M., Free, R., Wiebe, P.H., and Bé, A.W.H., 1982. Vertical distribution and isotopic fractionation of living planktonic foraminifera from the Panama Basin. Nature, 298:841-844.

Fairbanks, R.G., and Wiebe, P.H., 1980. Foraminifera and chlorophyll maximum: vertical distribution, seasonal succession, and paleoceanographic significance. Science, 209:1524-1526.

Fairbanks, R.G., Wiebe, P.H., and Bé, A.W.H., 1980. Vertical distribution and isotopic composition of living planktonic foraminifera in the western North Atlantic. Science, 207:61-63.

Farrell, J.W., and Prell, W.L., 1989. Climatic change and $\mathrm{CaCO}_{3}$ preservation: an 800,000 year bathymetric reconstruction from the central equatorial Pacific Ocean. Paleoceanography, 4:447-466.

, 1991. Pacific $\mathrm{CaCO}_{3}$ preservation and $\delta^{18} \mathrm{O}$ since $4 \mathrm{Ma}$ : paleoceanic and paleoclimatic implications. Paleoceanography, 6:485-498.

Howard, W.R., and Prell, W.L., 1992. Late Quaternary surface circulation of the southern Indian Ocean and its relationship to orbital variations. Paleoceanography, 7:79-117.

Hutson, W.H., 1979. The Agulhas Current during the late Pleistocene: analysis of modern faunal analogs. Science, 207:64-66.

Hutson, W.H., and Prell, W.L., 1980. A paleoecological transfer function, FI2, for Indian Ocean planktonic foraminifera. J. Paleontol., 54:381-399.

Imbrie, J., Hays, J.D., Martinson, D.G., McIntyre, A., Mix, A.C., Morley, J.J., Pisias, N.G., Prell, W.L., and Shackleton, N.J., 1984. The orbital theory of Pleistocene climate: support from a revised chronology of the marine $\delta^{18} \mathrm{O}$ record. In Berger, A., Imbrie, J., Hays, J., Kukla, G., and Saltzman, B. (Eds.), Milankovitch and Climate (Pt. 1), NATO ASI Ser. C, Math Phys. Sci., 126: Dordrecht (D. Reidel), 269-305.

Kipp, N.G., 1976. New transfer function for estimating past sea-surface conditions from sea-bed distribution of planktonic foraminiferal assemblages in the north Atlantic. In Cline, R.M., and Hays, J.D. (Eds.), Investigation of Late Quaternary Paleoceanography and Paleoclimatology. Mem.Geol. Soc. Am., 145:3-41.
Le, J., and Shackleton, N.J., 1992. Carbonate dissolution fluctuations in the western equatorial Pacific during the late Quaternary. Paleoceanography, 7:21-42.

Ortner, P.B., Wiebe, P.H., and Cox, J.L., 1980. Relationship between oceanic epizooplankton distributions and seasonal deep chlorophyll maximum in the northwestern Atlantic Ocean. J. Mar. Res., 38:507-531.

Overpeck, J.T., Webb, T., III, and Prentice, I.C., 1985. Quantitative interpretation of fossil pollen spectra: dissimilarity coefficients and the method of modern analogs. Quat. Res., 23:87-108.

Parker, F.L., and Berger, W.H., 1971. Faunal and solution patterns of planktonic Foraminifera in surface sediments of the South Pacific. Deep-Sea Res. Part A, 18:73-107.

Peterson, L.C., and Prell, W.L., 1985. Carbonate dissolution in Holocene sediments of the eastern equatorial Indian Ocean: preservation patterns and carbonate loss above the lysocline. Mar. Geol., 64:259-290.

Prell, W.L., 1985. The stability of low-latitude sea-surface temperatures: an evaluation of the CLIMAP reconstruction with emphasis on the positive SST anomalies. Dept. Energy Tech. Rep., TR-025.

Prell, W.L., and Damuth, J.E., 1978. The climate related diachronous disappearance of Pulleniatina obliquiloculata in Late Quaternary sediments of the Atlantic and Caribbean. Mar. Micropaleontol., 3:267-277.

Prell, W.L., Imbrie, J., Martinson, D.G., Morley, J.J., Pisias, N.G., Shackleton, N.J., and Streeter, H.F., 1986. Graphic correlation of oxygen isotope stratigraphy: application to the late Quaternary. Paleoceanography, 1:137-162.

Prentice, I.C., 1980. Multidimensional scaling as a research tool in Quaternary palynology: a review of theory and methods. Rev. Palaeobot. Palynol., 31:71-104.

Ravelo, A.C., and Fairbanks, R.G., 1992. Oxygen isotopic composition of multiple species of planktonic foraminifera: recorders of the modern photic zone temperature gradient. Paleoceanography, 7:815-831.

Ravelo, A.C., Fairbanks, R.G., and Philander, G., 1990. Reconstructing tropical Atlantic hydrography using planktonic foraminifera and an ocean model. Paleoceanography, 5:409-431.

Raymo, M.E., Ruddiman, W.F., Shackleton, N.J., and Oppo, D.W., 1990. Evolution of Atlantic-Pacific $\delta^{13} \mathrm{C}$ gradients over the last 2.5 m.y. Earth Planet. Sci. Lett., 97:353-368.

Thompson, P.R., 1976. Planktonic foraminiferal dissolution and the progress towards a Pleistocene equatorial Pacific transfer function. J. Foraminiferal Res., 6:208-227.

1981. Planktonic foraminifera in the western North Pacific during the past 150,000 years: comparison of modern and fossil assemblages. Palaeogeogr., Palaeoclimatol., Palaeoecol., 35:241-279.

Date of initial receipt: 8 December 1995

Date of acceptance: 6 May 1996

Ms 154SR-111 